\author{
ZBIGNIEW ANUSIK \\ https://orcid.org/0000-0002-5483-4970 \\ Uniwersytet Łódzki
}

\title{
LATYFUNDIUM TECCZYŃSKICH W XVII WIEKU. DOBRA I WŁAŚCICIELE
}

\begin{abstract}
Abstrakt: Tęczyńscy herbu Topór od XIV do XVII w. należeli do ścisłej elity możnowładczej a następnie magnackiej Królestwa Polskiego, później Rzeczypospolitej Obojga Narodów. Dziejom tego rodu poświęcono bardzo dużo miejsca w polskiej literaturze historycznej. Stosunkowo niewiele pisano jednak o należących do Tęczyńskich majątkach. Wydawać by się mogło, że zarówno genealogia tej rodziny, jak i dzieje należącego do niej latyfundium nie kryją już żadnych tajemnic. Badania podjęte przez autora przeczą jednak temu mniemaniu. W prezentowanym tu artykule, przy okazji przedstawiania dziejów latyfundium rodziny Tęczyńskich w XVII w. dokonano kilku istotnych korekt i uzupełnień dotyczących stosunków rodzinnych i dziejów życia przedstawicieli dwóch ostatnich pokoleń tej możnej i zasłużonej dla kraju rodziny.
\end{abstract}

Słowa kluczowe: Tęczyńscy herbu Topór, dobra ziemskie Tęczyńskich w XVII w., latyfundia magnackie, genealogia, magnateria polska przełomu XVI i XVII w., dzieje Rzeczypospolitej w XVI i XVII w.
Abstract: From the fourteenth to the seventeenth century, the Tęczyński family of the Topór coat of arms belonged to belonged to the magnate power elite in the Kingdom of Poland and later in the Polish-Lithuanian Commonwealth. Much space has been devoted to the history of this family in Polish historical literature. Relatively little has been written, however, about the estates belonging to the Tęczynskis. It might appear that the story of this family holds no mysteries. The author's research demonstrates that there are. This article explores the history of the Tęczyński latifundium in the seventeenth century, and makes some significant corrections and additions to the family relations and history of the last two generations of this powerful family, which played a significant role in its time.

Keywords: Tęczyńskis of the Topór coat of arms, Tęczyńskis' landed estates in the seventeenth century, magnate latifundia, genealogy, Polish magnates at the turn of the seventeenth century, history of the Commonwealth in the sixteenth and seventeenth centuries. 
Tęczyńscy herbu Topór byli jednym z najznakomitszych możnowładczych, a następnie magnackich rodów małopolskich. Ich znaczenie wynikało m.in. z faktu, że osiągniętą na początku XIV w. pozycję polityczną, majątkową i społeczną potrafili utrzymać aż do śmierci ostatniego męskiego potomka rodziny w 1637 r. Jest sprawą oczywistą, że dzieje tego rodu od dawna przyciągały uwagę kolejnych pokoleń badaczy. Stosunkowo niewiele pisano natomiast o majątkach, które pozostawały w rękach panów na Tęczynie. Niezbyt wiele informacji na ten temat znalazło się np. w klasycznej pracy Abdona Kłodzińskiego ${ }^{1}$. W obszernej monografii Janusza Kurtyki omówiono z kolei przede wszystkim losy podkrakowskich dóbr Tęczyńskich skupionych wokół zamku w Tęczy$n^{2} e^{2}$. Warto również wspomnieć o opracowaniu pióra Zbigniewa Anusika, będącym swego rodzaju pendant do ustaleń Kurtyki dotyczących dóbr ziemskich należących do panów z Tęczyna w XIV-XVII w. ${ }^{3}$

Przeprowadzona przez autora niniejszego artykułu rozległa kwerenda archiwalna pozwoliła skorygować wiele twierdzeń zawartych w przywołanych tu tekstach i rzucić zupełnie nowe światło na dzieje rodu Tęczyńskich i jego latyfundium w XVII w. Zanim przejdziemy do omówienia zagadnień zasygnalizowanych w tytule, wypada odnotować, że przedmiotem naszego zainteresowania są przedstawiciele dwóch ostatnich pokoleń rodu Tęczyńskich, a więc dzieci i wnuki Andrzeja Tęczyńskiego († $22 \mathrm{~V}$ 1588), wojewody krakowskiego i Zofii z Dembowskich herbu Jelita († 23-24 V 1588), wojewodzianki bełskiej. Wspomniana tu para pozostawiła po sobie cztery córki - Agnieszkę, Katarzynę, Izabelę i Zofię, oraz trzech synów - Gabriela, Andrzeja i Jana Magnusa. Po śmierci Andrzeja i Zofii Tęczyńskich opiekę nad ich potomstwem objął starszy brat wojewody krakowskiego - Jan Tęczyński († 1 I 1593), kasztelan wojnicki i podkomorzy koronny. On też zarządzał całym latyfundium Tęczyńskich. Po zgonie kasztelana wojnickiego wszystkie dobra należące do panów na Tęczynie przeszły drogą naturalnej sukcesji w ręce jego bratanków ${ }^{4}$.

${ }^{1}$ A. Kłodziński, Tęczyńscy. Pogląd na rozwój, zamożność i znaczenie rodu, „Sprawozdania Komisyi do badania Historyi Sztuki” 9, 1913, szp. 243-260.

${ }^{2}$ J. Kurtyka, Latyfundium tęczyńskie. Dobra i właściciele (XIV-XVII wiek), Kraków 1999.

3 Z. Anusik, Dobra ziemskie Tęczyńskich w XIV-XVII wieku, w: idem, Studia i szkice staropolskie, Łódź 2011, s. 175-217. Por. też idem, Latyfundia panów na Tęczynie. Kilka refleksji w związku z książka Janusza Kurtyki, „Przegląd Nauk Historycznych” 2, 2003, 2 (4), s. 217-256.

${ }^{4}$ W. Dworzaczek, Genealogia, t. 2 (Tablice), Warszawa 1959, tabl. 94; J. Kurtyka, op. cit., s. 203-212; Z. Ossoliński, Pamiętnik, oprac. J. Długosz, Warszawa 1983, s. 35-36. Warto w tym miejscu dodać, że kasztelan wojnicki Jan Tęczyński pozostawił po sobie 
Na wieść o śmierci stryja młodzi Tęczyńscy przerwali studia we Włoszech, ale po tymczasowym uporządkowaniu swoich spraw majątkowych ponownie tam wyjechali. W czasie nieobecności wojewodziców krakowskich w kraju ich najstarsza siostra Agnieszka (*12 I 1578 † 16 VI 1644) 13 października 1594 r. poślubiła wojewodę krakowskiego Mikołaja Firleja herbu Lewart († 22 III 1600). Miała z nim trójkę dzieci - syna Jana oraz córki Zofię i Krystynę. Po wczesnym owdowieniu oddała się dewocji. U schyłku życia ufundowała klasztor Karmelitów bosych w Czernej oraz szpitale w Bejscach, Rogowie i Iwanowicach ${ }^{5}$. W 1596 r. Gabriel, Andrzej i Jan Tęczyńscy pojawili się na krótko w granicach Rzeczypospolitej. Zapewne właśnie wówczas powierzyli swojemu szwagrowi, wojewodzie krakowskiemu Mikołajowi Firlejowi, zarząd wszystkich swoich majątków. Rozliczenia z Firlejem mieli dokonać po zakończeniu

liczne potomstwo nieślubne. Ze szlachcianką Anną Strzeszkowską miał syna Marcjana oraz córki Magelonę, Dianę, Krystynę i Mariannę. Król Zygmunt III legitymizował wszystkie te dzieci 20 lutego 1596 r. z nazwiskiem matki. Z nieznaną z imienia chłopką z Piotraszówki miał natomiast Tęczyński syna Jana i córkę, którzy używali nazwiska Piotraszowscy. Jan Piotraszowski przez długie lata pozostawał w służbie Tęczyńskich, a jego siostra wyszła za innego długoletniego sługę kasztelana wojnickiego - niejakiego Podoskiego. Por. „Legitimatio liberorum naturalium Magnifici olim Castel. Voinicensis”, AGAD, MK 140, k. 60-60v.; W. Nekanda Trepka, Liber generationis plebeanorum (,Liber chamorum"), cz. 1: Wstępy wydawców i tekst, wyd. W. Dworzaczek, J. Bartyś, Z. Kuchowicz, red. W. Dworzaczek, Wrocław-Warszawa-Kraków 1963, nr 1125, 1536, 1565; J. Kurtyka, op. cit., s. 204.

${ }^{5}$ Dodajmy, że Agnieszka z Tęczyńskich Firlejowa była użytkowniczką dzierżaw: wolbromskiej w województwie krakowskim i przybysławickiej w województwie lubelskim. Obie te królewszczyzny z czasem odstąpiła synowi. Po jego śmierci (Jan Firlej zmarł przez 18 grudnia 1640 r.) bez powodzenia próbowała dokonać cesji Wolbromia na swojego siostrzeńca, Franciszka Hieronima Gostomskiego i jego żonę, Mariannę z Gembickich. Nie udało się jej również utrzymać w swoich rękach Przybysławic. Z córek Agnieszki, starsza - Zofia (w zakonie Izabela) została benedyktynką w Chełmnie, gdzie złożyła śluby zakonne w 1612 r. Data jej śmierci nie jest znana. Młodsza - Krystyna wstąpiła do zakonu brygidek w Lublinie, gdzie odbywała nowicjat w 1616 r. Zmarła w roku 1648. Por. A. Kłodziński, op. cit., szp. 242-243; W. Urban, Daty życia niektórych osób z XVI w. związanych z Krakowem. Przyczynki źródłowo-biograficzne, „Biuletyn Biblioteki Jagiellońskiej” 41, 1991, s. 93; K. Lepszy, Firlejowa Agnieszka, PSB, t. 7, Kraków 1948-1958, s. 17-18; C. Gil, Karmelici bosi w Polsce 1605-1655, „Nasza Przeszłość” 18, 1977, s. 114-125; K. Chłapowski, Realizacja reform egzekucji dóbr 1563-1665. Sprawa zastawów królewszczyzn małopolskich, Warszawa 1984, s. 215; Rejestr poborowy województwa lubelskiego (powiat lubelski i urzędowski z r. 1626, ziemia łukowska zr. 1620), oprac. J. Kolasa, K. Schuster, red. S. Inglot, Wrocław 1957 (dalej: Rejestr lubelski 1626), s. 15-16; J. Kurtyka, op. cit., s. 208-209; Konsens królewski na cesję dzierżawy wolbromskiej przez wojewodzinę krakowską Agnieszkę Firlejową na rzecz Franciszka Gostomskiego, AGAD, MK 186, k. 237-238; M. Borkowska, Zakonnice pominięte w tablicach Dworzaczka, „Nasza Przeszłość” 97, 2002, s. 268. 
zagranicznych wojaży. Ostateczny powrót młodych Tęczyńskich do kraju nastąpił prawdopodobnie pod koniec $1599 \mathrm{r}$. W styczniu $1600 \mathrm{r}$. wydali oni bowiem za mąż swoją drugą siostrę - Katarzynę (*29 I 1581 † 6 XII 1648), która poślubiła wojewodę lubelskiego Marka Sobieskiego herbu Janina († 10 XI 1605). Już 7 lutego 1600 r. świeżo upieczona wojewodzina lubelska, po otrzymaniu posagu i wyprawy, ustąpiła na rzecz braci z wszystkich dóbr ojczystych i macierzystych. W małżeństwie z Markiem Sobieskim Tęczyńska urodziła syna Jana (*ok. 1600 † 1627). Po wczesnym owdowieniu nie wyszła ponownie za mąż. Przeżyła męża, syna i pasierba, kasztelana krakowskiego Jakuba Sobieskiego, ojca przyszłego króla Jana III ${ }^{6}$.

22 marca 1600 r. zmarł wojewoda krakowski Mikołaj Firlej, który przez ostatnie lata zarządzał dobrami Tęczyńskich. Jego śmierć spowodowała liczne komplikacje. Szwagier młodych Tęczyńskich nie zdążył bowiem rozliczyć się z nimi ze sprawowanego przez siebie zarządu. W tej sytuacji panowie na Tęczynie stanęli wobec konieczności wyegzekwowania należnych im sum od spadkobierców wojewody krakowskiego. W roku 1606 wspólnie wytoczyli proces synom Mikołaja Firleja - Mikołajowi (zm. 1635) i Janowi (zm. 1640). Oskarżali ich ojca o zagarnięcie dochodów $\mathrm{z}$ administrowanych przez niego dóbr (tu swoje pretensje wycenili na 60 tys. grzywien) oraz przejęcie wierzytelności przekazanych na jego ręce przez dłużników ojca i stryja braci Tęczyńskich - Jana Firleja, podskarbiego wielkiego koronnego i Mikołaja Kazimierskiego (w tym przypadku chodziło o sumę 24 tys. florenów). Sprawa została zawieszona w 1608 r. w związku z małoletnością siostrzeńca Tęczyńskich - Jana.

${ }^{6}$ J. Kurtyka, op. cit., s. 146-147, 211-212; W. Urban, op. cit., s. 94; W. Dworzaczek, Genealogia, t. 2, tabl. 148; „Magnifica Catherina de Tenczyn Palatina Lublinensis abrenunciat”, AP w Lublinie, Lubelskie ziemskie, Wieczyste (dalej: LZW), nr 90, k. 360-360v.; "Comitibus in Tenczyn a M. Sobieska de eadem Tenczyn Palatina Lublinensis donatio", ibidem, k. 396-396v. (Katarzyna z Tęczyna Sobieska rezygnuje na rzecz braci z dóbr macierzystych, czyli z włości stołpińskiej w woj. ruskim i kilku wsi w woj. bełskim). H. Gmiterek, Sobieski Marek, PSB, t. 39, Warszawa-Kraków 1999-2000, s. 504 (tu jednak błędna informacja, że Jan Sobieski był synem pierwszej żony wojewody lubelskiego, Jadwigi ze Snopkowskich); „Succesores Palatini Lublinensis contumaces”, AP w Lublinie, Lubelskie ziemskie, Sądowe (dalej: LZS), nr 60, k. 26-26v.; „Sobieska Palatina Lublinensis et succesores Palatini Lublinensis contumaces”, ibidem, k. 177 (tu jednoznaczne stwierdzenie, że Jan Sobieski był synem Marka i Katarzyny Tęczyńskiej); „Daniłowiczowa ac Opalińska protestantur", AP w Lublinie, Lubelskie grodzkie, Relacje [dalej: LGR], nr 77, k. 633; „Thesauraria Regni ac Succameraria Posnanensis relatio”, ibidem, k. 725v. (tu data śmierci Katarzyny Sobieskiej, która zmarła w dniu św. Mikołaja 1648 r.); Z. Anusik, Dwa ostatnie pokolenia Tęczyńskich herbu Topór. Kilka korekt i uzupełnień dotyczacych genealogii rodu, PH 111, 2020, 4, s. 727-728. 
Została jednak wznowiona w 1612 r. i trwała jeszcze w roku 1617, kiedy to po śmierci Andrzeja i jego dzieci proces z Firlejami kontynuowali Gabriel i Jan Magnus?.

12 stycznia 1601 r. bracia Tęczyńscy dokonali w Lublinie podziału dóbr ziemskich, które odziedziczyli po rodzicach i stryju. Dzięki zachowanej umowie podziałowej możemy bardzo dokładnie odtworzyć kształt należącego do nich latyfundium. W początkach XVII stulecia w posiadaniu Tęczyńskich znajdowały się majątki położone w województwach krakowskim, sandomierskim, lubelskim, bełskim i ruskim, składające się z 3 zamków, 4 miast, 111 wsi całych, 5 części wsi, 1 wsi pustej, 41 folwarków i 3 dworów w Krakowie. W skład masy spadkowej wchodziły również bliżej nieokreślone sumy zabezpieczone na częściach dwóch innych $\mathrm{wsi}^{8}$. Na dział najstarszego z braci, Gabriela, przypadł klucz końskowolski w województwie i powiecie lubelskim. W jego skład wchodziło miasto Końskowola z zamkiem oraz wsie Chrzochów (Krzochów), Chrzochówek (Krzochówek), Demba (Dęba), Młynki, Nowodwór z folwarkiem, Opoka, Osiny z folwarkiem, Parchatka, Popów, Pożóg z folwarkiem, Pulka (Pólka) z folwarkiem, Puławy, Rudy, Siedlec, Skowieszyn z folwarkiem, Stara Wieś z folwarkiem, Witowice z folwarkiem, Włostowice z folwarkiem, Wola Osińska, Wólka (Wola Profecińska), Wronów i Zbędowice z folwarkiem. Dział ten obejmował również włość krasiejowską w województwie ruskim, powiatach halickim i kołomyjskim, a więc miasto Krasiejów, wsie Krzywotuły, Peczeniżyn, Pulwrony (Pulurowy), Rungury, Stawy oraz sumy na części wsi Przybyłów. Spośród dworów krakowskich Gabrielowi przypadł w udziale dwór Pod Topory. W sumie najstarszy z braci Tęczyńskich objął w posiadanie dobra, które składały się z 1 zamku, 2 miast, 27 wsi, 9 folwarków, 1 dworu w Krakowie i sumy zabezpieczonej na części 1 wsi ${ }^{9}$.

${ }^{7}$ J. Kurtyka, op. cit., s. 148. Warto w tym miejscu dodać, że swoje pretensje kierowali Tęczyńscy również pod adresem braci zmarłego szwagra - Andrzeja, Jana i Henryka Firlejów, jako opiekunów ich siostrzeńca - Jana. Por. „Inter Firleje et Tęczyńskie motio”, AP w Lublinie, LZS, nr 54, k. 854v.-857; „Inter Tęczyńskie et Firleje”, ibidem, k. 881-885.

8 „Joannes comes in Tenczyn inscriptionem [--] transportat”, ANK, Castriensia Cracoviensia Inscriptiones (dalej: CCI) 172, s. 1509-1517 (akt podziałowy przeniesiony do ksiąg grodzkich krakowskich przez Jana Tęczyńskiego); „Gabriel comes in Tenczyn divisionem transportat”, AP w Lublinie, Lubelskie ziemskie, Wieczyste i zobowiązania [dalej: LZWZ], nr 105, k. 191-193v. (akt podziałowy przeniesiony do ksiąg ziemskich lubelskich przez Gabriela Tęczyńskiego). Warto zwrócić uwagę na fakt, że w obu wersjach aktu podziałowego pominięto wieś Popów (Pępów), która z całą pewnością wchodziła wówczas w skład klucza końskowolskiego.

9 "Joannes comes in Tenczyn inscriptionem [--] transportat", ANK, CCI 172, s. 1511; „Gabriel comes in Tenczyn divisionem transportat”, AP w Lublinie, LZWZ, 
Średni z braci Tęczyńskich - Andrzej, objął majętność rytwiańsko-łubnicką w województwie sandomierskim, powiatach sandomierskim i wiślickim. W jej skład wchodziły: zamek Rytwiany „ze strzelbą”, miasto Staszów oraz wsie Borki, Budziska z folwarkiem, Czarzyzna, Gorzechów (pusta), Góra, Grabowa, Kłoda, Koniemłoty z folwarkiem, Łubnice z folwarkiem, Niedziałki albo Toporów, Niemścice, Oględów z folwarkiem, Orzelec (Orlec) Mały, Orzelec (Orlec) Wielki, Orzeł z folwarkiem, Otałęska Wola, Otałęż, Przeczów, Ruda, Rytwiany z folwarkiem, Sieragi z folwarkiem, Stara Wieś, Stary Staszów, Szczeka z folwarkiem, Szydziny (Sydzina), Świchów (Sichów Duży) z folwarkiem, Świchowiec (Sichów Mały), Święcica, Tatary, Tuklęcz, Wolica, Zaraz i Zrębin. W dziale Andrzeja znalazł się także klucz jakubowicki w województwie i powiecie lubelskim. Obejmował on Jakubowice z murowanym dworem i folwarkiem, wsie Długie (część) z folwarkiem, Rudniczek, Świdniczek z folwarkiem, Świdnicka Wola (Wólka) oraz sumy zabezpieczone na części wsi Żuków. W tym samym powiecie do Andrzeja należeć miały również wsie Stawce, Studzianki i Wola Studzieńska. W województwie ruskim, powiecie lwowskim średni z braci Tęczyńskich objął majętność stołpińską, w skład której wchodził Stołpin z dworem i folwarkiem oraz wsie Andrzejówka (Jędrzejówka), Bołożynów (Położynów), Iwaśków (Hirajków), Kobyle, Lojtków (Lejtków), Przewłoczna, Turza i Wola. W skład schedy Andrzeja weszły również wsie Hulcze (połowa) z folwarkiem i Chochłów (połowa) w województwie i powiecie bełskim oraz wieś Honiatycze z folwarkiem w tym samym województwie, ale w powiecie grabowieckim. W Krakowie średniemu z braci Tęczyńskich przypadł dwór Malowany. Poza tym, wspólnie z młodszym bratem Janem miał on użytkować spichlerz we Włostowicach we włości końskowolskiej. W sumie zatem Andrzej Tęczyński objął w $1601 \mathrm{r}$. dobra składające się z 1 zamku, 1 miasta, 49 wsi całych, 1 wsi pustej, 3 części wsi, 15 folwarków, 1 dworu w Krakowie oraz sum zabezpieczonych na części $1 \mathrm{wsi}^{10}$.

nr 105, k. 191v. Dodajmy w tym miejscu, że o ile włość końskowolska stanowiła zwarty kompleks majątkowy, o tyle osady majętności krasiejowskiej były rozrzucone na dość dużym obszarze i znacznie od siebie oddalone. W atlasie Aleksandra Jabłonowskiego zlokalizowano Krasiejów, Krzywotuły, Peczyniżyn i Rungury (dwie ostatnie wsie oznaczono błędnie jako królewszczyzny) oraz Przybyłów. Por. Atlas historyczny Rzeczypospolitej Polskiej, Epoka przełomu z wieku XVI-go na XVII-ty, Dział II-gi, „Ziemie ruskie” Rzeczypospolitej, oprac. A. Jabłonowski, Warszawa-Wiedeń 1899-1904 (dalej: Atlas historyczny Rzeczypospolitej), mapa 3. Nie udało się natomiast ustalić położenia i, w przypadku tej pierwszej, właściwej nazwy wiosek Pulwrony (Pulurowy) oraz Stawy.

10 "Joannes comes in Tenczyn inscriptionem [-- transportat”, ANK, CCI 172, s. 1511-1512; „Gabriel comes in Tenczyn divisionem transportat”, AP w Lublinie, LZWZ, nr 105, k. 191v.-192. Warto w tym miejscu zaznaczyć, że na mapie województwa 
Najmłodszy z braci, Jan Magnus, objął dział, na który składała się przede wszystkim majętność tęczyńska w powiecie proszowskim województwa krakowskiego. Był to zamek Tęczyn „ze strzelbą” i folwarkiem, miasto Nowa Góra oraz wsie Baczyn (część) z folwarkiem, Brzoskwinia z folwarkiem, Cholerzyn, Chrosna, Czermna (Czerna), Czyźówka, Filipowice z folwarkiem, Frywałd, Grodziec z folwarkiem, Kępa, Krzeszowice z folwarkiem, Miękinia, Młynka, Morawica z folwarkiem, Myślachowice z folwarkiem, Nawojowa Góra z folwarkiem, Nielepice, Morawica, Ostrożnica, Prądnik z młynem Hanesz, Rudno, Siersza, Tenczynek z folwarkiem, Wodna, Wola Filipowska, Wólka i Zalas. Do działu Jana Magnusa należały też leżące w powiecie proszowskim, ale oddalone dość znacznie od zwartego kompleksu dóbr tęczyńskich wsie Jankowice z folwarkiem i Obrazowice (Obrażejowice) z folwarkiem, jak również wsie Giebułtów z folwarkiem, Maciejów, Małoszów i Tuchołów w województwie krakowskim, powiecie ksiąskim. W tym samym województwie, ale w powiecie śląskim miał on także wsie Bachowice $\mathrm{z}$ folwarkiem i Grodzisko $\mathrm{z}$ folwarkiem. W województwie i powiecie bełskim do Jana Magnusa należała majętność przewodowska, w skład której wchodziły wsie Przewodów z dworem i folwarkiem oraz Budzyń (Budynin) z folwarkiem. Uzupełnienie tego działu stanowiły: połowa wsi Strzeszkowice w województwie lubelskim oraz dwór Wielki przy bramie Wiślnej w Krakowie. Ponadto Jan Magnus wspólnie z bratem Andrzejem miał użytkować spichlerz we Włostowicach w dobrach końskowolskich. W sumie zatem, od chwili przeprowadzenia działu z braćmi, Jan Magnus Tęczyński był właścicielem 1 zamku, 1 miasta, 35 wsi całych, 2 część wsi, 17 folwarków i 1 dworu w Krakowie ${ }^{11}$.

Pomimo dokonanego podziału dóbr bracia Tęczyńscy wspólnie realizowali niektóre przedsięwzięcia o charakterze majątkowym. Razem prowadzili wspomniany wyżej spór z Firlejami. Procesowali się również

sandomierskiego w drugiej połowie XVI w. nie umieszczono wsi Borki, Gorzechów, Niedziałki albo Toporów, Sieragi oraz Tatary. Por. Województwo sandomierskie $w$ drugiej połowie XVI wieku, red. W. Pałucki, cz. 1: Mapy, plany, Warszawa 1993 (Atlas historyczny Polski. Mapy szczegółowe XVI wieku, 2), mapa 1. Z kolei w atlasie Jabłonowskiego w granicach włości stołpińskiej zaznaczono jedynie Stołpin, Bołożynów (Położynów), Kobyle, Przewłoczną i Turzę, pominięto natomiast Andrzejówkę, Iwaśków, Lojtków i Wolę. Zamiast nich wydawca umieścił na mapie Brahówkę, Dajmaki, Hutę Starą i Łabacz, co sprawia, że liczba osad tej majętności równa jest liczbie wymienionej w układzie podziałowym. Por. Atlas historyczny Rzeczypospolitej, mapa 3.

11 „Joannes comes in Tenczyn inscriptionem [- - transportat”, ANK, CCI 172, s. 1512-1513; „Gabriel comes in Tenczyn divisionem transportat”, AP w Lublinie, LZWZ, nr 105, k. 192-192v. Warto dodać, że oprócz wymienionego w akcie podziałowym dworu Wielkiego, Jan Magnus miał też w Krakowie dwór Tęczyński, który przejęła po nim później jego jedyna córka Izabela. Por. J. Kurtyka, op. cit., s. 224. 
przez długie lata z dziećmi Katarzyny z Tęczyńskich $1^{\circ}$ v. księżny Słuckiej, $2^{\circ}$ v. Radziwiłłowej, a więc Krzysztofem ks. Radziwiłłem, hetmanem polnym litewskim i Elżbietą z ks. Radziwiłłów Sapieżyną, żoną kanclerza wielkiego litewskiego Lwa Sapiehy. Spór ten, ciągnący się jeszcze w latach dwudziestych XVII w., był konsekwencją zadawnionych pretensji Katarzyny z Tęczyńskich do połowy klucza tęczyńskiego w województwie krakowskim, przejętej po śmierci jej brata, wojewody bełskiego Jana Chrzciciela w 1563 r. przez Jana i Andrzeja Tęczyńskich, a więc stryja i ojca Gabriela, Andrzeja i Jana Magnusa ${ }^{12}$. W roku 1609 bracia Tęczyńscy wydali za mąż swoją trzecią siostrę - Zofię († 1620), która poślubiła Jana Gostomskiego herbu Nałęcz († 12 III 1623), wówczas starostę wałeckiego, z czasem zaś wojewodę kaliskiego. Miała z nim jedynego syna, Franciszka Hieronima (*ok. $1610 \dagger$ ok. 1647), z czasem podkomorzego czerskiego. Ten ostatni w roku 1636 ożenił się z Marianną Gembicką herbu Nałęcz, córką Stefana, wówczas kasztelana rogozińskiego, a później wojewody łęczyckiego. Również i ten siostrzeniec Tęczyńskich (podobnie jak Jan Firlej i Jan Sobieski) zmarł jednak bezpotomnie ${ }^{13}$.

\section{Gabriel Tęczyński, wojewoda lubelski}

Po podziale przeprowadzonym w 1601 r. latyfundium Tęczyńskich rozpadło się na trzy części. Omówienie dziejów poszczególnych majętności rozpocząć wypada od przedstawienia poczynań najstarszego z braci.

12 J. Kurtyka, op. cit., s. 147; „Inter Sapiehy et Radziwiłł ac comites a Tenczyn scrutinio termini”, AP w Lublinie, LZS, nr 64, k. 710v.-712; „Inter Radziwiłł, Sapiehy et comites a Tenczyn motio", LZS, nr 65, k. 483v.-486v.

${ }^{13}$ Zofia była najmłodszą córką wojewody krakowskiego Andrzeja. W akcie skwitowania Stanisława Żółkiewskiego przez Tęczyńskich została bowiem wymieniona na ostatnim miejscu wśród dzieci wojewody. Możemy zatem założyć, że urodziła się w 1586 lub 1587 r. Por. Jan Tęczyński w imieniu dzieci brata Andrzeja kwituje Stanisława Żółkiewskiego z sumy 16 tys. zł zapisanej na starostwie hrubieszowskim, AGAD, MK 135, k. 515v.-517. 19 września 1609 r. Zofia z Tęczyna Gostomska dokonała donacji dóbr po matce na rzecz braci Andrzeja i Jana Magnusa, którzy władali nimi od 1601 r. Por. „Zophia de Tenczyn Gostomska fratribus germanis sortes bonorum maternorum donat", AGAD, MK 153, k. 78-80. Por. też A. Boniecki, Herbarz polski, t. 6, Warszawa 1903, s. 347; W. Dworzaczek, Gostomski Jan, PSB, t. 8, Wrocław-Warszawa-Kraków 1959-1960, s. 366367; idem, Genealogia, t. 2, tabl. 94; J. Kurtyka, op. cit., s. 212; K. Niesiecki, Herbarz polski, t. 9, wyd. J.N. Boborowicz, Lipsk 1842, s. 65; „Adiudicatio annorum generosi Francisci Gostomski olim Magnifici Joannis Gostomski Palatini Calissiensis filii”, AGAD, MK 176, k. 15v.-16 (Zygmunt III „dodaje” lat niepełnoletniemu F.H. Gostomskiemu; E. Opaliński, Rodziny wielkosenatorskie w Wielkopolsce, na Kujawach i na Mazowszu za Zygmunta III. Podstawy karier, Warszawa 2007, s. 285; Z. Anusik, Dwa ostatnie pokolenia, s. 728-729. 
Gabriel urodził się 23 lutego 1575 r. koło Kraśnika. W maju 1593 r. otrzymał nadanie dzierżawy Uścieczko oraz kilku innych wsi w województwie ruskim, powiatach lwowskim, halickim i kołomyjskim (wszystkie te dobra od 7 marca 1591 r. trzymał wspólnie ze stryjem Janem, kasztelanem wojnickim). Dzierżawa Uścieczko stanowiła zwarty kompleks osadniczy, graniczący od zachodu ze starostwem śniatyńskim. Pozostałe wsie leżały w sporym od niej oddaleniu. Użytkowane przez Gabriela Tęczyńskiego dobra domeny obejmowały miasteczko Uścieczko Tęczyńskie alias Uście Biełotwy oraz wsie Bełełuja, Brostów (Berestowica), Dziurów, Frankowce, Głuskowo, Jesieniów, Karłów, Koza (Kossa), Krasnostawce, Łaski (Laski), Niżny Kąt, Ostrowole, Podwysokie, Tarchowica alias Turowice, Toporowce, Tuczempy (Tuczapy), Wołowo, Wrusów i Zakrzowce, razem 1 miasto i 19 wsi. Dobra te Tęczyński zachował do śmierci. Przed 12 stycznia 1601 r. najstarszy z braci Tęczyńskich otrzymał urząd miecznika koronnego (występował z nim w akcie podziałowym). 30 kwietnia 1606 r. został zaś wojewodą lubelskim. Urząd ten piastował do końca życia. Gabriel Tęczyński zmarł przed 28 września 1617 r., a 30 stycznia 1618 r. został pochowany staraniem najmłodszego brata Jana Magnusa w kościele dominikańskim św. Trójcy w Krakowie ${ }^{14}$.

Pan na Końskowoli i Krasiejowie starał się bez powodzenia o rękę Eleonory, starszej córki bardzo bogatego kasztelana krakowskiego Janusza ks. Ostrogskiego. Ostatecznie panna została wydana za Hieronima Jazłowieckiego, z czasem wojewodę podolskiego ${ }^{15}$. W 1602 r. Gabriel poślubił jednak równie posażną pannę, gdyż jego żoną została Barbara ks. Zbaraska herbu Korybut (*ok. $1582 \nmid 1602)$, córka kniazia Stefana († 1585), wojewody trockiego i Doroty Firlejówny († 1591), kasztelanki lubelskiej. Wraz z ręką Barbary przejął w zarząd ogromne latyfundium jej ojca. Do ślubu doszło prawdopodobnie w pierwszym kwartale 1602 r. 29 kwietnia

${ }^{14}$ A. Kłodziński, op. cit., szp. 242; W. Urban, op. cit., s. 93; Nadanie dzierżawy Uścieczko Gabrielowi Tęczyńskiemu, AGAD, MK 133, k. 547-547v.; Nadanie dzierżawy Uścieczko kasztelanowi wojnickiemu Janowi Tęczyńskiemi i jego bratankowi Gabrielowi, MK 136, k. 126v.-127v. Dodajmy w tym miejscu, że w atlasie Jabłonowskiego w granicach dzierżawy uścieckiej (nieoznaczonej zresztą jako królewszczyzna) zaznaczono jedynie następujące osady: Bełełuja, Dziurów, Karłów, Krasnostawce, Toporowce, Uście i Tuczempy (Tuczapy). Por. Atlas historyczny Rzeczypospolitej, mapa 7; Z. Ossoliński, op. cit., s. 36, 101; W. Dworzaczek, Genealogia, t. 2, tabl. 94; J. Kurtyka, op. cit., s. 206-207 (tu m.in. błędna informacja, że Gabriel Tęczyński był w latach 1606-1608 kasztelanem lubelskim); Urzędnicy, t. 4, z. 4, nr 375; Konsens królewski na wykupienie dóbr Uścieczko przez Jana Tęczyńskiego od spadkobierców jego brata Gabriela, AGAD, MK 161, k. 168-169.

${ }^{15}$ W. Sokołowski, Politycy schyłku złotego wieku. Małopolscy przywódcy szlachty i parlamentarzyści w latach 1574-1605, Warszawa 1997, s. 99; T. Chynczewska-Hennel, Ostrogski Janusz, PSB, t. 24, Wrocław 1979, s. 485. 
tego roku do ksiąg Trybunału Koronnego w Lublinie wpisano bowiem akt zrzeczenia się opieki nad wojewodzianką trocką przez jej braci stryjecznych, Janusza ks. Zbaraskiego, wojewodę bracławskiego i Piotra ks. Zbaraskiego. Tego samego dnia obaj opiekunowie przekazali w ręce małżonków Tęczyńskich wszystkie dobra po Stefanie ks. Zbaraskim. Były to następujące majątki: w województwie brzesko-litewskim miasto Międzyrzec z przyległościami; w powiecie orszańskim miasto i zamek Biłhorod oraz dobra Teteryn (Ciecierzyn); w powiecie mścisławskim dobra Kosza, Packów i Pacałków; w powiecie mińskim zamek i miasto Mołodeczno „z folwarkami, wsiami i dworami”, dwór Sieliszcze, dwór Bakszty oraz dwór i miasteczko Wołma; w powiecie oszmiańskim dobra Zaberezie (Zabrzezie), dwór Hruzdów, dwór Narocz wraz z wsiami na Urzeczu, dwór i miasteczko Kobylniki, dwór Rabynia i dwór Uzła; w powiecie mozyrskim wieś Brabica; dwór w Wilnie na przedmieściu „z folwarkiem i obudowaniem i z innemi folwarkami"; w powiecie horodelskim dwór Stoka; w powiecie krzemienieckim na Wołyniu zamek i miasto Ożohowce i dwór Biełozorka; w województwie podolskim miasteczko Kupiel z przyległościami. W skład latyfundium wojewody trockiego wchodziły również dwory Szlany, Ponyzany, Lepejkiszka, Kowalowa i Grondziszki, których położenia nie udało się ustalić. Przy ostrożnym szacunku można przyjąć, że dobra odziedziczone po ojcu przez Barbarę ze Zbaraskich Tęczyńską obejmowały 4 zamki, 7 miast i miasteczek oraz nie mniej niż $175 \mathrm{wsi}^{16}$.

Szczęście małżeńskie Gabriela i Barbary Tęczyńskich nie trwało jednak długo. Młoda żona miecznika koronnego zmarła bowiem już w $1602 \mathrm{r}$. Żyła jeszcze 30 września tego roku, kiedy to jej mąż pisał z Międzyrzeca do swojej siostry, Katarzyny z Tęczyńskich Sobieskiej. Barbara załączyła bowiem pozdrowienia dla szwagra i szwagierki. W przywołanym tu liście znalazła się jednak wzmianka, że Gabriel zamierza właśnie wyjechać $z$ Międzyrzeca, ale niepokoi go choroba żony ${ }^{17}$. Niedługo potem, 12 października 1602 r. miecznikowa koronna pożegnała się z tym światem. Przed śmiercią zdążyła jednak zapisać mężowi dobra międzyrzeckie ${ }^{18}$.

${ }^{16}$ W. Dworzaczek, Genealogia, t. 2, tabl. 94; J. Kurtyka, op. cit., s. 207; Ziemie Ruskie, Ukraina (Kijów-Bracław), dział 2, wyd. A. Jabłonowski, Warszawa 1893 (Źródła dziejowe, t. 21, Polska XVI wieku pod względem geograficzno-statystycznym, t. 10), s. 434-435; Z. Anusik, Dobra ziemskie Tęczyńskich, s. 203-204; idem, Dobra ziemskie książąt Zbaraskich w XVI i XVII wieku, w: idem, Studia i szkice, s. 503-504.

${ }^{17}$ Gabriel Tęczyński do Katarzyny z Tęczyńskich Sobieskiej, Międzyrzec 30 IX 1602, BC, sygn. MNK VIII-A. 871/19.

${ }^{18} \mathrm{Z}$ całą pewnością był to akt darowizny, a nie zapis testamentowy, co w konsekwencji umożliwiło Gabrielowi Tęczyńskiemu, a następnie również i jego spadkobiercom, utrzymanie się $\mathrm{w}$ posiadaniu tych dóbr. W sprawie daty śmierci Barbary 
Niespełna rok po śmierci pierwszej żony Gabriel Tęczyński ożenił się ponownie. 19 sierpnia 1603 r. poślubił w Nieświeżu Elżbietę ks. Radziwiłłównę herbu własnego (1585-1618), córkę Mikołaja Krzysztofa „Sierotki" (1549-1616), wojewody wileńskiego (od marca 1604) i Eufemii ks. Wiśniowieckiej († 1596), wojewodzianki wołyńskiej, która wniosła mu 50 tys. florenów posagu i bogatą wyprawę (30 tys. florenów w klejnotach i srebrze $)^{19}$.

Zanim przejdziemy do omówienia dziejów latyfundium pozostającego we władaniu Gabriela Tęczyńskiego, warto może najpierw wyjaśnić kilka kwestii związanych z jego najbliższą rodziną. $\mathrm{O}$ ile bowiem temat obu małżeństw najstarszego z braci Tęczyńskich został dobrze objaśniony $\mathrm{w}$ literaturze przedmiotu, o tyle sprawę pozostawionego przez niego potomstwa gruntownie zagmatwano. Adam Boniecki, Włodzimierz Dworzaczek i Janusz Kurtyka przypisali mu bowiem córkę Teofilę († 1635), wydaną jakoby przed 1617 r. za Aleksandra Kopcia herbu Kroje († 1651), z czasem kasztelana brzesko-litewskiego. Dwaj ostatni badacze twierdzili również, że Teofila była córką Barbary ks. Zbaraskiej $^{20}$. Tymczasem okazało się, że Teofila z Tęczyna wcale nie była córką Gabriela Tęczyńskiego. Co więcej, nie pochodziła nawet z rodu Tęczyńskich. Koronnym dowodem na to jest ogłoszone drukiem kazanie Modesta Pierzakowicza wygłoszone na jej pogrzebie w Opolu 13 lutego 1635 r. Wynika z niego niezbicie, że Teofila z Tęczyna Kopciowa była córką innego wojewody lubelskiego, Piotra Aleksandra Tarły (pochodzącego z tej linii rodu Tarłów, która konsekwentnie pisała się nie ze Szczekarzewic, a właśnie z Tęczyna) i jego pierwszej żony, Zofii z Działyńskich, wojewodzianki chełmińskiej ${ }^{21}$.

Tęczyńskiej por. A. Filipczak-Kocur, Proces o spadek po księżniczce Barbarze Zbaraskiej-Tęczyńskiej, w: Vetera novis augere. Studia i prace dedykowane profesorowi Wacławowi Uruszczakowi, t. 1, red. S. Grodziski [et al.], Kraków 2010, s. 221-222; Z. Anusik, Dwa ostatnie pokolenia, s. 729-730.

19 A. Sajkowski, Staropolska miłość. Z dawnych listów i pamiętników, Poznań 1981, s. 54-57; W. Dworzaczek, Genealogia, t. 2, tabl. 94; J. Kurtyka, op. cit., s. 207; H. Lulewicz, Radziwiłł Mikołaj Krzysztof zwany Sierotka, PSB, t. 30, Wrocław 1987, s. 359; Z. Anusik, Dobra ziemskie Tęczyńskich, s. 205. Warto dodać, że drugi teść Gabriela Tęczyńskiego szybko wywiązał się ze swoich zobowiązań finansowych. Już 11 listopada 1604 r. miecznik koronny skwitował bowiem „Sierotkę” z drugiej i ostatniej raty posagu. Por. T. Kempa, Mikołaj Krzysztof Radziwiłt Sierotka (1549-1616), wojewoda wileński, Warszawa 2000, s. 228.

20 A. Boniecki, op. cit., t. 11, Warszawa 1907, s. 115; W. Dworzaczek, Genealogia, t. 2, tabl. 94; J. Kurtyka, op. cit., s. 207, 212-213. Podobnie Z. Anusik, Dobra ziemskie Tęczyńskich, s. 205-206.

${ }^{21}$ M. Pierzakowicz, Gorskość śmierci na pogrzebie Theophili z Tęczyna Kopciowey woiewodzanki lubelskiey w kościele opolskim wspomniona, Lublin [1635], s. [12]. Prawidłowo 
Nie ulega natomiast najmniejszej nawet wątpliwości, że Gabriel Tęczyński był ojcem Zofii. Dworzaczek uznał, że pochodziła ona z drugiego małżeństwa swojego ojca. Pogląd ten zakwestionował jednak Kurtyka, który stwierdził, że ze względu na prawa do Międzyrzeca musiała być ona córką Gabriela i Barbary ks. Zbaraskiej. Ponieważ zaś małżeństwo to było wyjątkowo krótkotrwałe założył, że Zofia Tęczyńska była bliźniaczą siostrą Teofili. Wywód Kurtyki wydawał się na tyle przekonujący, że sam do niedawna także podzielałem ten pogląd ${ }^{22}$. Dziś jednak muszę przyznać się do pomyłki. Istnieją bowiem przynajmniej trzy przekazy źródłowe potwierdzające, że Zofia Tęczyńska była córką Gabriela i jego drugiej żony, Elżbiety z ks. Radziwiłłów. Najważniejszy z nich, to zapiska kanclerza wielkiego litewskiego Albrychta Stanisława ks. Radziwiłła, który w swoim „Memoriale” odnotował, że na wieść o śmierci Jana Magnusa Tęczyńskiego, zmarłego w lipcu 1637 r., marszałek nadworny litewski Aleksander Ludwik ks. Radziwiłł, wuj i naturalny opiekun wojewodzianki lubelskiej Zofii Tęczyńskiej, dokonał zajazdu dóbr międzyrzeckich i trzymał ten majątek w swoich rękach aż do chwili zamążpójścia jego siostrzenicy ${ }^{23}$. O rodzicach Zofii z Tęczyna (myląc zresztą ich imiona) wspomniał też $\mathrm{w}$ panegiryku ogłoszonym z okazji jej ślubu z podskarbim wielkim koronnym Janem Mikołajem Daniłowiczem Jan Cynerski Rachtamowicz ${ }^{24}$. Przodków Zofii z domu Tęczyńskich i Radziwiłłów sławił także inny panegirysta - Marcin Hińcza ${ }^{25}$. Możemy zatem uznać kwestię pochodzenia

zidentyfikował Teofilę również Mariusz Lubczyński, autor biogramu jej prawdziwego ojca, idem, Tarło Piotr Aleksander (Aleksander Piotr), PSB, t. 52, Warszawa-Kraków 20182019, s. 313 (tu informacja, że Teofila z Tarłów została wydana za Aleksandra Kopcia dopiero w 1633 r.). Warto zauważyć, że dokładnie takie same ustalenia dotyczące pochodzenia i małżeństwa Teofili z Tęczyna Kopciowej podała wcześniej Anna Filipczak-Kocur. Autorka ta, nie dostrzegając wagi tego odkrycia, uznała jednak, że obok Teofili Tarłówny musiała istnieć również Teofila Tęczyńska, bliźniacza siostra Zofii. W ślad za Januszem Kurtyką powtórzyła też błędne stwierdzenie, że Teofila i Zofia Tęczyńskie były córkami Gabriela i Barbary ks. Zbaraskiej. Por. A. Filipczak-Kocur, op. cit., s. 222; oraz Z. Anusik, Dwa ostatnie pokolenia, s. 731.

22 W. Dworzaczek, Genealogia, t. 2, tabl. 94; J. Kurtyka, op. cit., s. 207, 213; Z. Anusik, Dobra ziemskie Tęczyńskich, s. 206, 208-209.

23 A.S. Radziwiłł, Memoriale rerum gestarum in Polonia 1632-1656, t. 2: 1634-1639, oprac. A. Przyboś, R. Żelewski, Wrocław 1970, s. 249-250.

${ }^{24}$ J. Cynerski Rachtamowicz, Thesaurus meritorum. Ad festum Nuptiale Illustrissimi ac Magnifici Dni, D. Ioannis Nicolai a Zurow Daniłowicz, Supremi Thesaurarij Regni, Praemislien. Samborien. Drohobycen. Colsen. Korsunen. Ratinen. etc. etc. etc. Capitanei. Et Lectissimae Virginis Sophiae Comitissae a Tęczyn, Illustriss: olim et Mag. Dni, Stanislai Comitis a Tęczyn, Palatini Lublinensis unicae Filiae, Cracoviae 1638, s. [13]-[15].

25 M. Hińcza, Plęsy anyołow Jezusowi narodzonemu, najswiętszego Krzyża tance, Kraków 1636 [właściwie 1638], s. [20]-[21]. Por. też Z. Anusik, Dwa ostatnie pokolenia, s. 732. 
Zofii Tęczyńskiej za ostatecznie rozstrzygniętą. Była ona córką wojewody lubelskiego Gabriela i jego drugiej żony, Elżbiety z ks. Radziwiłłów.

Warto w tym miejscu również wspomnieć, że Gabriel Tęczyński oprócz córki miał także dwóch synów. Obaj pochodzili z jego drugiego małżeństwa. Starszy z nich - Krzysztof, przyszedł na świat w sierpniu 1604 r. Młodszy - Jan, urodził się zapewne mniej więcej rok później. Wzmianki o starszym z synów Elżbiety z Radziwiłłów Tęczyńskiej pojawiały się często w jej listach do ojca, wojewody wileńskiego Mikołaja Krzysztofa Radziwiłła „Sierotki”. Pozdrowień od Krzysia dla dostojnego dziadka zabrakło dopiero w liście pisanym przez jego matkę 10 grudnia $1613 \mathrm{r}$. Oznacza to, że musiał on umrzeć przed tą datą. O Janie wspomniała natomiast Elżbieta tylko raz. W liście pisanym z Międzyrzeca w 1609 r. informowała ojca, że jej mąż wyjechał do Częstochowy, zabierając ze sobą małego Jasia. Być może to właśnie młodszego z synów wojewody lubelskiego dotyczy też wzmianka źródłowa związana z działalnością publiczną Gabriela Tęczyńskiego, który swoją nieobecność na sejmie 1611 r. usprawiedliwił niespodziewaną śmiercią syna. W każdym razie obaj synowie Gabriela Tęczyńskiego zmarli w dzieciństwie. Żaden z nich nie dożył 10 roku życia ${ }^{26}$.

Wiosną 1602 r., po przejęciu latyfundium Stefana ks. Zbaraskiego, Gabriel Tęczyński stał się jednym z największych właścicieli ziemskich w całej Rzeczypospolitej. Jego dobra ziemskie składały się wówczas z dziewięciu miast i ponad 200 wsi. Sytuacja ta nie trwała jednak długo. Wszystko uległo bowiem zmianie po rychłym zgonie jego pierwszej żony, która zmarła bezpotomnie 12 października 1602 r. ${ }^{27}$ Umierająca w wieku niespełna 20 lat Barbara ze Zbaraża Tęczyńska zdążyła przed śmiercią sporządzić testament. Mężowi zapisała dożywocie na wszystkich majątkach 300 tys. kop groszy litewskich (750 tys. złotych) na dobrach w Wielkim Księstwie Litewskim oraz wszystkie ruchomości. Niemal natychmiast po śmierci Barbary swoje pretensje do spadku po niej zgłosili jednak jej prawni spadkobiercy, czyli potomkowie braci wojewody trockiego - Mikołaja, Jerzego i Władysława ks. Zbaraskich. Wytoczyli oni wojewodzie lubelskiemu kilka procesów, usiłując przejąć zapisane mu przez żonę w dożywocie majątki. Stosunkowo szybko udało

${ }^{26}$ Omówienie przywołanej tu korespondencji Elżbiety Tęczyńskiej z ojcem por. A. Sajkowski, Staropolska miłość, s. 61-66. Por też J. Byliński, Sejm z 1611 roku. W nowym opracowaniu, Wrocław 2016, s. 104; Z. Anusik, Dobra ziemskie Tęczyńskich, s. 205.

27 A. Filipczak-Kocur, op. cit., s. 221-222. Źródłowe potwierdzenie bezpotomnej śmierci Barbary z ks. Zbaraskich Tęczyńskiej por. „Successorum Palatini Vilnensis intromissio”, AP w Lublinie, LGR, nr 44, k. 521v.; „Eiusdem altera (lecta ex copia)”, ibidem, k. 522v. (tu jednak żona Gabriela Tęczyńskiego nazwana została Anną ks. Zbaraską). 
się Tęczyńskiemu zawrzeć ugodę z potężnymi panami na Zbarażu. Nie jest jedynie pewne, czy nastąpiło to jeszcze za życia wojewody bracławskiego Janusza ks. Zbaraskiego († 1608), czy też dopiero po jego śmierci. W każdym razie, w zamian za ustąpienie im przez Tęczyńskiego (który mógł przy tej okazji otrzymać również jakąś rekompensatę finansową) wszystkich dóbr po wojewodzie trockim na Wołyniu i Podolu (z Ożohowcami, Białozorką i miasteczkiem Kupiel), Zbarascy z linii starosty krzemienieckiego Mikołaja zrzekli się wszelkich roszczeń do Międzyrzeca oraz do litewskich dóbr po księżniczce Barbarze ${ }^{28}$.

Co ciekawe, praw Tęczyńskiego do klucza międzyrzeckiego nie usiłowali podważać również pozostali spadkobiercy jego żony. Wszyscy oni, a więc potomkowie czterech córek księcia Jerzego Zbaraskiego (Naruszewiczowie, Wołłowiczowie, Miękiccy i Bełżeccy) oraz dwóch córek księcia Władysława (Szemiotowie i Charlęscy) wysuwali natomiast różnego rodzaju pretensje do majątków litewskich. Można przypuszczać, że przynajmniej część tych dóbr została zajęta przez krewnych Barbary. Patrząc zaś na całą sprawę przez pryzmat sytuacji finansowej Gabriela Tęczyńskiego, należy założyć, że majątki na Litwie, które zdołał utrzymać w swoich rękach, nie przynosiły mu zbyt dużych dochodów. Główny proces ze spadkobiercami pierwszej żony toczył Tęczyński w latach 1602-1617 w sądzie ziemskim brzesko-litewskim. Ostatecznie sprawa trafiła jednak do Trybunału Głównego Litewskiego, który 26 kwietnia 1617 r. przyznał sporne dobra krewnym księżniczki Barbary. Przed objęciem tych włości w realne posiadanie mieli oni jednak wypłacić Gabrielowi Tęczyńskiemu zapisaną mu przez żonę sumę 300 tys. kop groszy litewskich. Niemal natychmiast po zapadnięciu tego wyroku wojewoda lubelski podjął próbę przejęcia części majątków po pierwszej żonie na własność, nabywając od jej spadkobierców ich prawa do Mołodeczna. Ostatecznie jednak zrezygnował z planów uzyskania dóbr dziedzicznych na Litwie i jeszcze w 1617 r. scedował wszystkie zapisy dokonane na jego rzecz przez Barbarę ks. Zbaraską (w tym sumę 300 tys. kop groszy litewskich na dobrach w Wielkim Księstwie Litewskim) ojczymowi pierwszej żony, kanclerzowi wielkiemu litewskiemu Lwu Sapieże. Ten zaś, obejmując $\mathrm{w}$ realne posiadanie duże latyfundium po pasierbicy, zaspokajał stopniowo pretensje jej krewnych, na co przeznaczył wcale nie nazbyt wygórowaną kwotę 113 tys. złotych (florenów) ${ }^{29}$.

${ }^{28}$ A. Filipczak-Kocur, op. cit., s. 222; Z. Anusik, Latyfundia książąt Zbaraskich w XVI i XVII wieku, „Przegląd Nauk Historycznych” 8, 2009, 1, s. 49; idem, Dobra ziemskie książat Zbaraskich, s. 525.

${ }^{29}$ A. Filipczak-Kocur, op. cit., s. 223-225; Z. Anusik, Dwa ostatnie pokolenia, s. 733. 
Wyjaśnienie kwestii związanych z losami dawnego latyfundium wojewody trockiego Stefana ks. Zbaraskiego zmienia w dość istotny sposób perspektywę oceny finansowych poczynań Gabriela Tęczyńskiego. Przed kilkoma laty (przyjmując błędnie, że Barbara ze Zbaraskich była matką Zofii Tęczyńskiej) napisałem, że poprzez swoją fatalną gospodarkę wojewoda lubelski utracił ogromną większość dóbr wniesionych mu przez wojewodziankę trocką ${ }^{30}$. W rzeczywistości jednak należałoby spojrzeć na tę sprawę zupełnie inaczej. Rezygnując z dóbr na Wołyniu i Podolu, Tęczyński zdobył bowiem dla siebie i swoich spadkobierców bogaty klucz międzyrzecki, utrzymując jednocześnie więcej niż poprawne stosunki z potężnymi krewnymi pierwszej żony, kasztelanem krakowskim Jerzym i koniuszym koronnym Krzysztofem ks. Zbaraskimi. Przez długie lata walczył również o utrzymanie w swoim ręku majątków litewskich. Dokonując zaś cesji swoich praw do tych dóbr na rzecz Lwa Sapiehy, otrzymał z pewnością jakąś rekompensatę finansową. W sumie jednak dochody, które Tęczyński mógł czerpać ze spornych dóbr litewskich, w niewielkim tylko stopniu wpłynęły na poprawę jego sytuacji majątkowej. Potrzebując nieustannie znacznej ilości gotówki, doprowadził on bowiem do sporego zadłużenia dóbr odziedziczonych po rodzicach. Zamykając zaś kwestię losów dawnego latyfundium wojewody trockiego, wspomnieć trzeba, że w 1627 r., a więc już po śmierci młodszego brata, kasztelan krakowski Jerzy ks. Zbaraski darował Dadźbogowi Kierle, zasłużonemu klientowi i słudze księcia koniuszego, dobra Mołodeczno, Białynicze, Ciecierzyn (Teteryn), Paczków, Olany i kilka innych, które przypadły mu w udziale drogą „naturalnej sukcesji” po Barbarze ze Zbaraskich, żonie Gabriela Tęczyńskiego, wojewody lubelskiego ${ }^{31}$.

Warto w tym miejscu zaznaczyć, że summa summarum rozstrzygnięcie kwestii spadku po pierwszej żonie okazało się bardzo korzystne dla Gabriela Tęczyńskiego. Klucz międzyrzecki stanowił bowiem najcenniejszą część dawnego latyfundium Stefana ks. Zbaraskiego. Po jego objęciu,

30 Z. Anusik, Dobra ziemskie Tęczyńskich, s. 205.

31 „Idem Illustris Castellanus Cracoviensis Kierłowi donat”, ANK, CCI 227, s. 11611165. Należy w tym miejscu wyraźnie zaznaczyć, że kasztelan krakowski nie miał prawa przekazać Kierle tych majątków, gdyż wraz z nieżyjącym już bratem dokonał cesji wszelkich roszczeń do litewskich dóbr po Barbarze ze Zbaraskich na rzecz Gabriela Tęczyńskiego. Sam obdarowany nie zainicjował oczywiście żadnych kroków zmierzających do wejścia w posiadanie tych majętności. Jego syn, Gabriel Kierło podjął natomiast w 1635 r. próbę odprzedania swoich wątpliwych praw do Mołodeczna, Ciecierzyna, Białynicz i Horodyszcza synowi Lwa Sapiehy, Kazimierzowi Leonowi. Ostatecznie jednak młody Sapieha wycofał się z tej nieuczciwej transakcji. Por. A. Rachuba, Sapieha Kazimierz Leon, PSB, t. 35, Warszawa-Kraków 1994, s. 35; A. Filipczak-Kocur, op. cit., s. 224-227; Z. Anusik, Dwa ostatnie pokolenia, s. 733. 
dobra ówczesnego miecznika koronnego powiększyły się o 1 miasto, 45 wsi i 11 folwarków. Były to następujące miejscowości: miasto Stary i Nowy Międzyrzec, wsie Bojarskie, Bereza z folwarkiem, Dołha, Drelów z folwarkiem, Grabowiec z folwarkiem, Jelnica, Koszeliki, Kożuszki, Krzewica, Krzymoszyce, Kwasówka, Łaniów, Łuby, Łukowisko, Łózki (Łuzki), Manie, Misie, Muchy (Muszyki), Obelnik, Ostrówki z folwarkiem, Pereszczówka, Pościsze, Przechodzisko, Przychody, Puchacze, Rogoźnica z folwarkiem, Rudniki, Rzeczyca, Sitno, Sitno (drugie), Sówki, Stołpno, Strzakły, Surmacze, Szachy, Szóstka, Tłuściec, Tuliłów, Utrówka, Worsza, Wólka (Krzymowska), Wólka (Łózecka), Wygnanka, Zasiadki, Żerocin z folwarkiem oraz niezwiązane bezpośrednio z żadną ze wsi folwarki Dołhołęka, Hałasy, Przyłuki, Zadworny i Żabie ${ }^{32}$. Przejęcie na własność rozległych dóbr międzyrzeckich na krótko tylko poprawiło sytuację majątkową Gabriela Tęczyńskiego. Okazał się on bowiem niezbyt rządnym gospodarzem i wiódł życie zdecydowanie ponad stan. W konsekwencji doprowadził do znacznego zadłużenia swoich majątków, a pogarszająca się sytuacja finansowa zmusiła go do oddania włości końskowolskiej w ręce posesorów zastawnych.

W końcu lipca 1609 r. wojewoda lubelski zastawił za 40 tys. florenów miasto Końskowolę z zamkiem oraz wsie Młynki, Nowodwór z folwarkiem, Popów, Pulkę (Pólkę) z folwarkiem, Rudy, Siedlec z folwarkiem, Starą Wieś z folwarkiem i Wólkę z folwarkiem swojej bratowej, Katarzynie z Leszczyńskich Tęczyńskiej, kasztelanowej wiślickiej33. W początkach sierpnia tego samego roku Tęczyński sprzedał (z prawem odkupu) za 60 tys. florenów swojemu szwagrowi, staroście wałeckiemu Janowi Gostomskiemu wsie Włostowice z dworem i folwarkiem, Parchatka, Pożóg z folwarkiem, Puławy, Skowieszyn z folwarkiem, Witowice z folwarkiem, Wola Profecińska (Wólka) i Zbędowice z folwarkiem. W 1612 r. wojewoda lubelski zastawił natomiast za 20 tys. florenów stolnikowi gostynińskiemu Feliksowi Gorzewskiemu wsie Osiny z folwarkiem,

32 Osady wchodzące w skład włości międzyrzeckiej zostały wymienione w dwóch aktach podziału dóbr Opalińskich (spadkobierców Tęczyńskich) z roku 1668 i 1670. Por. „M.M. Opalińskich divisio”, ANK, CCI 292, s. 2423; „Eorundem M.M. Opalińskich divisio”, CCI 295, s. 196.

33 „M. Tęczyńska intromissio”, AP w Lublinie, LGR, nr 39, k. 390-391; „Palatinus Cracoviensis sorori sua cedit”, ANK, CCI 245, s. 1107-1108. Warto zwrócić uwagę na fakt, że w akcie intromisji Katarzyny Leszczyńskiej do dóbr końskowolskich wspomniano o dwóch nowych folwarkach, których nie wymieniono w akcie podziałowym z $1601 \mathrm{r}$. Były to folwarki w Siedlcu i w Wólce. Dodajmy również, że przy okazji przekazania Końskowoli bratowej, Gabriel Tęczyński skwitował z wszelkich pretensji dotychczasowego zarządcę klucza końskowolskiego i osińskiego - Dadźboga Kierłę. Por. „Kierło oblata”, AP w Lublinie, LGR, nr 39, k. 475-475v. 
Osińska Wola, Wronów oraz młyn we wsi Wólka (Wola Profecińska) ${ }^{34}$. Po przeprowadzeniu tych transakcji, w rękach Tęczyńskiego pozostawały jedynie wsie Chrzochów (Krzochów), Chrzochówek (Krzochówek) Demba (Dęba) i Opoka. Kilka lat później wojewoda lubelski zastawił jednak również i tę część klucza końskowolskiego. Latem 1616 r. (za zgodą Gabriela Tęczyńskiego) dobra trzymane przez Katarzynę Leszczyńską, wówczas już żonę Adama Sędziwoja Czarnkowskiego, oraz Jana Gostomskiego zostały wykupione za sumę dotychczasowych zastawów, czyli 100 tys. florenów przez koniuszego koronnego Krzysztofa ks. Zbaraskiego. Ten ostatni, dopłacając 20 tys. florenów, przejął z rąk wojewody lubelskiego również wspomniane wyżej cztery wioski ${ }^{35} .6$ kwietnia 1617 r. oblatowano w grodzie lubelskim umowę zawartą przez Gabriela Tęczyńskiego z Feliksem Gorzewskim i jego żoną, Katarzyną z Sokołowskich, na mocy której suma zastawu na kluczu osińskim została zwiększona do 33 tys. florenów $^{36}$. Gwoli uzupełnienia dodajmy, że po przejęciu Końskowoli koniuszy koronny Krzysztof ks. Zbaraski uczynił z niej swoją główną rezydencję. 14 czerwca 1617 r. zawarł z Gabrielem Tęczyńskim umowę, która stanowiła, że trzymane przez niego dobra będą mogły zostać wykupione za sumę zastawu powiększoną o 3 tys. florenów ${ }^{37}$. Przez następnych 10 lat Zbaraski władał Końskowolą i Włostowicami, podczas gdy Osiny z przyległościami pozostawały początkowo w rękach małżonków Gorzewskich.

34 „Tęczyński Castellani Bełsensis intromissio”, AP w Lublinie, LGR, nr 42, k. 119119v. (tu informacja, że Feliks Gorzewski odstąpił zastaw na Osinach z przyległościami Andrzejowi Tęczyńskiemu). Niedługo potem, najpewniej po śmierci kasztelana bełskiego, Gorzewski ponownie objął jednak w posiadanie wspomniane wyżej wioski. Por. „Palatinus Cracoviensis sorori sua cedit”, ANK, CCI 245, s. 1109.

35 „Illustris ac Magnificus ducis a Zbaraż intromissio”, AP w Lublinie, LGR, nr 46, k. 578-579 (intromisja Krzysztofa ks. Zbaraskiego do Końskowoli z przyległościami); „Dux a Zbaraż Cremenecensis Capitaneus intromissus”, ibidem, k. 671-672 (intromisja Krzysztofa ks. Zbaraskiego do Włostowic i innych wiosek trzymanych przez Jana Gostomskiego); „Dux in Zbaraż Magnifici Palatini Lublinensis quietat”, ANK, CCI 208, s. 785-787; „Palatinus Cracoviensis sorori sua cedit”, CCI 245, s. 1107-1109.

${ }^{36}$ Katarzyna z Sokołowskich, wdowa po Feliksie Gorzewskim, przenosi z ksiąg grodzkich stężyckich do ksiąg grodzkich lubelskich umowę zawartą z Gabrielem Tęczyńskim 7 II 1617 r., AP w Lublinie, LGR, nr 47, k. 262-265. Warto tu odnotować, że oprócz Osin, Woli Osińskiej i Wronowa, wśród wiosek zastawionych Gorzewskim znalazł się również Popów, a więc osada, która wcześniej znajdowała się w zastawie Katarzyny Leszczyńskiej i Krzysztofa ks. Zbaraskiego. Por. „Palatinus Cracoviensis sorori sua cedit”, ANK, CCI 245, s. 1109.

${ }^{37}$ Umowa między Zbaraskim a Tęczyńskim została wpisana do ksiąg grodu w Nowym Mieście Korczynie. W roku następnym książę koniuszy przeniósł ją do grodu lubelskiego. Por. „Ducis a Zbaraż Cremenecensi Capitanei oblata”, AP w Lublinie, LGR, nr 48, k. $37 \mathrm{v} .-38 \mathrm{v}$. 
Po śmierci Feliksa Katarzyna Sokołowska wniosła natomiast ten zastaw swojemu drugiemu mężowi, Remigianowi Lasockiemu. Dopiero 30 maja 1626 r. Zbaraski wykupił od Lasockich klucz osiński, stając się w ten sposób zastawnym posiadaczem całej włości końskowolskiej ${ }^{38}$. W rejestrze poborowym województwa lubelskiego z 1626 r. książę koniuszy występuje jako właściciel tego kompleksu majątkowego. W rzeczywistości jednak trzymał on tę majętność jedynie modo obligatorio w kwocie 153 tys. florenów ${ }^{39}$.

Oddanie w zastaw klucza końskowolskiego nie oznaczało wcale, że Gabriel Tęczyński nie posiadał od tej pory żadnych dóbr na terenie województwa lubelskiego. W 1610 r. nabył bowiem od Andrzeja Felicjana Ożarowskiego wsie Sowoklęski (Samoklęski), Sery (Wolę Serową) i Rudę. Nabytek ten okazał się trwały i wioski te na stałe weszły w skład latyfundium rodu Tęczyńskich ${ }^{40}$. Niewiele możemy natomiast powiedzieć o dobrach Gabriela położonych w województwie ruskim. Być może wyzbył się ich części w okresie, kiedy w poszukiwaniu nadzwyczajnych dopływów gotówki zastawiał kolejne wioski w majętności końskowolskiej ${ }^{41}$. Zasadniczy trzon dóbr ruskich wojewody lubelskiego pozostał jednak w posiadaniu Tęczyńskich przynajmniej do roku 1631. Na podkreślenie zasługuje też fakt, że Gabriel Tęczyński nie wyzbył się żadnej z użytkowanych przez siebie królewszczyzn ${ }^{42}$. Zamykając kwestie transakcji

38 „Palatinus Cracoviensis sorori sua cedit”, ANK, CCI 245, s. 1110.

39 W rejestrze poborowym z 1626 r. jako własność Krzysztofa ks. Zbaraskiego odnotowano miasto Końskowolę oraz wsie Chrzochów (Krzochów), Chrzochówek (Krzochówek), Demba (Dęba), Młynki, Opoka, Osiny, Parchatka, Popów (Pępów), Pożóg, Puławy, Rudy (Rudki), Siedlec, Skowieszyn, Stara Wieś, Witowice, Włostowice, Wola Osińska, Wola Profecińska (Wólka), Wronów i Zbędowice. W zestawieniu tym pojawiła się również pusta wieś Tęczyńska Wola, niewystępująca w akcie podziałowym z $1601 \mathrm{r}$. W rejestrze pominięto natomiast całkowicie wieś Pulkę (Pólkę), a Nowodwór określono jako dzierżawę Andrzeja Sierakowskiego. Por. Rejestr lubelski 1626, s. 136-139, 141. Gwoli wyjaśnienia dodajmy, że Krzysztof ks. Zbaraski, sam będąc zastawnym posesorem wsi Nowodwór z folwarkiem, zastawił ją 25 października 1622 r. Wojciechowi Mackiewiczowi. Por. „Idem eidem cedit”, ANK, CCI 245, s. 1119 (Jan Tęczyński ceduje na Agnieszkę Firlejową prawo do wykupienia zastawu od Mackiewicza).

40 SGKP, t. 10, Warszawa 1889, s. 254; „Sieniuta intromissio”, AP w Lublinie, LGR, nr 46, k. 91v.; „Palatini Lublinensis intromissio, ibidem, k. 91v.-92; „Tęczyńskich protestatio", LGR, nr 49, k. 241-241v.

${ }^{41}$ W zapisce archiwalnej pochodzącej z 1609 r. odnotowano, że Krasiejów był wówczas własnością Bartłomieja Polanowskiego. Nie jest to jednak informacja pewna. Być może Polanowski był tylko dzierżawcą lub zastawnikiem tych dóbr. Por. W. Łoziński, Prawem i lewem. Obyczaje na Czerwonej Rusi w pierwszej połowie XVII wieku, t. 2: Wojny prywatne, Kraków 1957 (wyd. 5), s. 74.

${ }^{42}$ Konsens królewski na wykupienie dóbr Uścieczko przez Jana Tęczyńskiego od spadkobierców jego brata Gabriela, AGAD, MK 161, k. 168-169. 
majątkowych dokonanych przez wojewodę lubelskiego, dodajmy, że przed rokiem 1616 sprzedał on dwór Pod Topory w Krakowie mieszczaninowi krakowskiemu i klientowi rodu Tęczyńskich - Krzysztofowi Falęckiemu ${ }^{43}$.

Podsumowując dokonania majątkowe Gabriela Tęczyńskiego, przyznać musimy, że ich bilans wypada całkiem dobrze. U schyłku życia wojewoda lubelski dysponował bowiem kluczem międzyrzeckim (1 miasto, 45 wsi i 11 folwarków), dobrami Sowoklęski (3 wsie), majętnością krasiejowską składającą się z kilku wsi oraz 1 miastem i co najmniej 19 wsiami królewskimi w województwie ruskim. W sumie było to więc 1 miasto i ponad 50 wsi prywatnych oraz 1 miasto i około 20 wsi królewskich ${ }^{44}$. Jeśli porównamy jego ówczesny stan posiadania z sytuacją z roku 1601 to okaże się, że liczba należących do niego osad uległa bardzo znaczącemu zwiększeniu. Dodajmy również, że od wiosny 1613 r. Gabriel Tęczyński wraz z najmłodszym bratem Janem Magnusem był opiekunem dzieci zmarłego właśnie wówczas średniego brata Andrzeja. Kiedy zaś w początkach 1617 r. również i ostatnie z dzieci Andrzeja rozstało się z tym światem, bracia Tęczyńscy odziedziczyli pozostałe po nich dobra ziemskie. Wojewoda lubelski nie zdołał jednak zapewne powiększyć swojego stanu posiadania, gdyż kilka miesięcy później zmarł. Już w 1616 r. Gabriel Tęczyński zapisał wieczyście dobra międzyrzeckie bratu Janowi Magnusowi z zastrzeżeniem dożywocia dla swojej drugiej żony. Elżbieta z Radziwiłłów przeżyła męża. W stanie wdowieńskim nie pozostała jednak zbyt długo. W pierwszym półroczu 1618 r. została bowiem żoną Krzysztofa Kiszki, w przyszłości wojewody witebskiego. Małżonkowie, zgodnie ze zwyczajem epoki, zeznali zapis wzajemnego dożywocia na wszystkich swoich dobrach nieruchomych i ruchomych. Elżbieta z Radziwiłłów $1^{\circ} \mathrm{v}$. Tęczyńska, $2^{\circ} \mathrm{v}$. Kiszkowa zmarła jednak już 30 listopada tego samego roku. Wdowiec, opierając swoje roszczenia na dokonanym przez Elżbietę zapisie dożywocia, objął w posiadanie Międzyrzec z wszystkimi przyległościami. Rychło jednak został z niego usunięty przez Jana Magnusa Tęczyńskiego, który dokonał zbrojnego zajazdu włości międzyrzeckiej i nie ustąpił z niej aż do swojej śmierci. Spór Tęczyńskiego z Kiszką udało się załagodzić dzięki interwencji króla Zygmunta III oraz pośrednictwu

43 W. Nekanda Trepka, op. cit., nr 430; J. Kurtyka, op. cit., s. 233.

${ }^{44}$ Liczba osad w królewszczyznach użytkowanych przez wojewodę lubelskiego mogła być nawet większa, gdyż w kancelarii królewskiej nie do końca orientowano się w stanie zasiedlenia poszczególnych królewszczyzn. We wszystkich aktach nadania dzierżawy uścieckiej, oprócz wyliczenia konkretnych wsi pojawia się bowiem określenie ,i inne”. 
specjalnej komisji z udziałem deputatów naznaczonych przez monarchę oraz przyjaciół zaproszonych przez strony konfliktu ${ }^{45}$.

Jedynym dzieckiem Gabriela Tęczyńskiego, które przeżyło ojca, była córka Zofia. Nie znamy daty jej urodzenia. Jak można przypuszczać, przyszła na świat nie wcześniej niż w 1606 r. i nie później niż na początku $1612 \mathrm{r}$. W swoim testamencie, zredagowanym 1 marca $1612 \mathrm{r}$. Mikołaj Krzysztof Radziwiłł „Sierotka” wspomniał bowiem o wnukach, dzieciach córki Elżbiety, co wobec śmierci w 1611 r. jednego z jej braci musiało oznaczać, że Zofia była już wówczas na świecie. To o niej właśnie pisał w swoim pamiętniku wojewoda sandomierski Zbigniew Ossoliński, który 30 stycznia 1618 r. uczestniczył w Krakowie w pogrzebie jej ojca: „Dziewczyna tylko po wojewodzie lubelskim została dote exhereditata" Rzeczywiście wyglądało na to, że jedyna córka Gabriela Tęczyńskiego została przez niego wydziedziczona. Przekazanie praw do Międzyrzeca bratu Janowi Magnusowi i zastawienie dóbr końskowolskich Krzysztofowi ks. Zbaraskiemu oraz małżonkom Gorzewskim oznaczało, że Zofia w przyszłości mogłaby liczyć jedynie na objęcie Sowoklęsk i włości krasiejowskiej. W gruncie rzeczy jednak jej sytuacja wcale nie wyglądała najgorzej. Nikt nigdy nie zakwestionował bowiem jej prawa do połowy dóbr ziemskich po zmarłych niedawno dzieciach Andrzeja Tęczyńskiego. Ponadto wiadomo było, że w prawie koronnym obowiązuje zasada beztestamentowego dziedziczenia dóbr ziemskich. Również w II i III Statucie litewskim ograniczono możliwość testamentowego rozporządzenia nieruchomościami jedynie do majątków nabytych przez testatora. Co prawda, Gabriel Tęczyński nie przekazał bratu praw do Międzyrzeca w testamencie, niemniej jednak nie dał mu nigdy faktycznej intromisji w dobra. To zaś mogło stanowić podstawę prawną do obalenia całego zapisu dokonanego w 1616 r. przez wojewodę lubelskiego. Zdawał sobie z tego doskonale sprawę Jan Magnus Tęczyński, który został opiekunem bratanicy. Dlatego też, chcąc zatrzymać należne Zofii majątki w rodzinie, planował

${ }^{45}$ A. Sajkowski, Staropolska miłość, s. 71-73; Z. Ossoliński, op. cit., s. 115-117; J. Kurtyka, op. cit., s. 207; T. Wasilewski, Kiszka Krzysztof, PSB, t. 12, Wrocław-Warszawa-Kraków 1966-1967, s. 510; Z. Anusik, Dobra ziemskie Tęczyńskich, s. 207-208. Dodajmy w tym miejscu, że akt ugody Jana Magnusa Tęczyńskiego z Krzysztofem Kiszką został oblatowany w grodach w Mielniku oraz w Brześciu Litewskim, co było z pewnością następstwem faktu, że w 1617 r. Międzyrzec z przyległościami przestał być częścią Wielkiego Księstwa Litewskiego, gdyż właśnie wówczas został włączony do ziemi mielnickiej województwa podlaskiego. 22 maja 1619 r. Jan Tęczyński w imieniu własnym oraz bratanicy Zofii wniósł z kolei do grodu krakowskiego zeznanie o wzajemnym skwitowaniu się z Kiszką z wszelkich pretensji. Por. „Kiszka quietatur”, ANK, CCI 212, s. 1808-1809.

${ }^{46}$ Z. Ossoliński, op. cit., s. 101. 
wydać ją za mąż za jednego ze swoich trzech synów. W tym celu podjął nawet podobno starania o uzyskanie w Rzymie stosownej dyspensy ${ }^{47}$. Wszyscy młodzi Tęczyńscy zmarli jednak jeszcze za życia ojca. Pomimo to Jan Magnus nadal opóźniał zamęście bratanicy i użytkował wszystkie dobra, które przejął po Gabrielu Tęczyńskim. Do śmierci stryja wojewodzianka lubelska pozostawała też pod jego opieką i nie mogła samodzielnie podejmować jakichkolwiek decyzji w sprawach majątkowych.

\section{Andrzej Tęczyński, kasztelan bełski}

Zanim przejdziemy do omówienia dalszych losów Zofii Tęczyńskiej, słów kilka wypada poświęcić dziejom tej części latyfundium Tęczyńskich, która przypadła w udziale średniemu z braci - Andrzejowi. Urodził się on 20 września 1576 r. w Kraśniku. Od 1588 r. użytkował starostwo stryjskie w województwie ruskim, czyli miasto Stryj oraz wsie Daszawa, Dobrzany, Duliby, Horowe, Hurnie, Kamionka, Koniuchów, Pobug, Styniawa Niżna, Styniawa Wyżna, Synowódzko Niżne, Synowódzko Wyżne, Truchanów, Urycze i Wolica Wowieńska, razem 1 miasto i 15 wsi. W 1602 r. wymienił Stryj z Adamem Stadnickim na starostwo horodelskie oraz dzierżawę dubieńską w województwie bełskim. Po przeprowadzeniu tego frymarku miał w dobrach domeny miasto Horodło z wsiami Czerniawka, Łuszków, Wólka Wydranicka i Wydranica oraz miasto Dubna (Dubienka) z wsiami Berezowiec, Kładniów, Starosiele alias Stara Wieś, Strzelce i Uchanka, razem 2 miasta i 9 wsi. W 1612 r. scedował starostwo horodelskie Olbrychtowi Łysakowskiemu. Dzierżawę dubieńską zachował zapewne do śmierci ${ }^{48} .1$ września 1603 r. Andrzej Tęczyński otrzymał nominację

47 A.S. Radziwiłł, op. cit., t. 2, s. 249-250; J. Kurtyka, op. cit., s. 207; Z. Anusik, Dobra ziemskie Tęczyńskich, s. 209; idem, Dwa ostatnie pokolenia, s. 734.

${ }^{48}$ W. Urban, op. cit., s. 93; A. Kłodziński, op. cit., szp. 242-243; W. Dworzaczek, Genealogia, t. 2, tabl. 94; J. Kurtyka, op. cit., s. 207-208; SGKP, t. 10, s. 437-438; K. Chłapowski, Starostowie w Małopolsce 1565-1668, w: Społeczeństwo staropolskie. Studia i szkice, t. 4, red. A. Izydorczyk, A. Wyczański, Warszawa 1986, s. 145 (tu jednak błędna informacja o nadaniu Andrzejowi Tęczyńskiemu starostwa stryjskiego w 1588 r.), 173. Warto w tym miejscu wyjaśnić kwestie związane z objęciem przez Andrzeja Tęczyńskiego starostwa stryjskiego. 23 lutego 1588 r. nadanie tej królewszczyzny otrzymał jego ojciec, wojewoda krakowski, który zmarł już trzy miesiące później. Tęczyńscy nie ustąpili jednak ze Stryja, a kancelaria królewska z czasem zaakceptowała tę uzurpację. Już na przełomie 1591 i 1592 r. młody Andrzej Tęczyński tytułowany był starostą stryjskim, przy czym zaznaczono, że pozostaje on pod opieką stryja Jana, kasztelana wojnickiego. Por. Nadanie starostwa stryjskiego wojewodzie krakowskiemu Andrzejowi Tęczyńskiemu, AGAD, MK 134, k. 207v.-208v.; Rozgraniczenie starostwa stryjskiego i dóbr dziedzicznych Jana 
na drążkową kasztelanię wiślicką. 6 lutego 1612 r. został kasztelanem bełskim. Zmarł przed 21 kwietnia $1613 \mathrm{r}$. w Warszawie i został pochowany 5 sierpnia tego roku w manierystycznej kaplicy własnej fundacji przy kościele parafialnym w Staszowie ${ }^{49}$.

Już w 1600 r. Andrzej Tęczyński ożenił się z liczącą wówczas zaledwie 12 lat Katarzyną Leszczyńską herbu Wieniawa $(* 1588$ † 1639), jedyną córką Jana († 1589), starosty radziejowskiego i Katarzyny z Opalińskich († ok. 1602), marszałkówny wielkiej koronnej. Wziął za nią 70 tys. florenów posagu, z czego 9 tys. przeznaczył na spłatę sumy posagowej swojej teściowej. Po ślubie objął w posiadanie dziedziczne dobra Katarzyny, a więc miasto Leszno z wsiami Drzeczkowo, Gronowo, Lasocice, Sienno i Strzyżowice $\mathrm{w}$ powiecie wschowskim i kościańskim oraz wieś Płowce w powiecie radziejowskim. Jeszcze w tym samym roku Katarzyna z Leszna Tęczyńska w asystencji i za zgodą męża odprzedała jednak te majętności swoim stryjom i dotychczasowym opiekunom, Andrzejowi i Wacławowi Leszczyńskim. Żonie oprawił Andrzej Tęczyński 60 tys. florenów posagu i drugie tyle wiana na połowie swoich dóbr. Katarzyna Leszczyńska urodziła mu dwoje dzieci: syna Hiacynta i pogrobową córkę Annę. Oboje zmarli jednak we wczesnym dzieciństwie, przed 14 kwietnia 1617 r. Wdowa po Andrzeju Tęczyńskim już w 1615 r. wyszła ponownie za mąż za Adama Sędziwoja Czarnkowskiego, wojewodę łęczyckiego i starostę generalnego Wielkopolski ${ }^{50}$.

i Mikołaja Daniłowiczów, MK 137, k. 230-244v. (tu młody Andrzej Tęczyński występuje jako starosta stryjski); Konsens królewski dla Andrzeja Tęczyńskiego na cesję starostwa stryjskiego Adamowi Stadnickiemu, MK 147, k. 212v.-213v.; Nadanie Andrzejowi Tęczyńskiemu w dożywotnie użytkowanie dzierżawy dubieńskiej, ibidem, k. 223v.-224; Konsens królewski na cesję przez Adama Stadnickiego starostwa horodelskiego Andrzejowi Tęczyńskiemu, ibidem, k. 266-267.

${ }^{49}$ Urzędnicy, t. 4, z. 3, nr 1214; Urzędnicy, t. 3, z. 2, nr 64, 829 i 830; Z. Ossoliński, op. cit., s. 56; W. Dworzaczek, Genealogia, t. 2, tabl. 94; J. Kurtyka, op. cit., s. 208.15 kwietnia 1613 r. Tęczyński sporządził testament. Na opiekunów dzieci, oprócz braci i żony, powołał kasztelana wiślickiego Rafała Leszczyńskiego oraz podkomorzego sandomierskiego Zbigniewa Lanckorońskiego. W osobnym akcie darował folwark i wójtostwo we wsi Andrzejówka (w dobrach staszowskich) swojemu zasłużonemu słudze Piotrowi Młodkowskiemu. Zapisał także 10 tys. florenów na wszystkich swoich dobrach niezamężnej siostrze Izabeli. Por. „Ordinatio generosi Andreas comitis de Tęczyn Castellani Bełzensis", AGAD, MK 155, k. 255-256v.

50 BK, Teki Dworzaczka (dalej: TD), Monografie, Leszczyńscy h. Wieniawa; Regesty, Zap. Tryb. Piotrk., 172 (Nr. 27), 1615 (dożywocie Czarnkowskich); Grodzkie i ziemskie (dalej: GiZ), Poznań, Rezygnacje, XVII wiek, Część 1, 7834 (Nr. 1412), 1620 (informacja o zapisach A. Tęczyńskiego na rzecz żony); J. Kurtyka, op. cit., s. 208 (tu m.in. niezbyt precyzyjne stwierdzenie, że Andrzej Tęczyński ożenił się z Leszczyńską przed 1612 r., a wdowa po nim poślubiła Adama Sędziwoja Czarnkowskiego około 1618 r.); Z. Anusik, Dwa ostatnie pokolenia, s. 736-737. 
W czasie swoich rządów w przypadającej na niego części latyfundium Tęczyńskich Andrzej założył miasto Toporów na terenie włości stołpińskiej. W dokumencie wydanym 1 września 1603 r. w Stołpinie nadał nowemu miastu herb i nazwę. Fundację tę zatwierdził Zygmunt III 24 lutego 1606 r., obdarzając osadę prawem magdeburskim. Już po śmierci Andrzeja, w 1628 r. jego brat Jan Magnus ufundował w Toporowie parafię rzymskokatolicką. W 1610 r. kasztelan wiślicki Andrzej Tęczyński podarował z kolei posiadany przez siebie dwór Malowany w Krakowie karmelitom bosym z przeznaczeniem na późniejszy klasztor św. Michała ${ }^{51}$. Nie dysponujemy żadnymi informacjami na temat innych jego transakcji majątkowych. Po wczesnej śmierci obojga dzieci kasztelana bełskiego wszystkie pozostałe po nim dobra spadły na jego braci. Kiedy zaś jeszcze w 1617 r. zmarł również wojewoda lubelski Gabriel Tęczyński, spadek po Andrzeju przypadł w udziale Janowi Magnusowi i córce Gabriela Zofii, która przez następnych 20 lat pozostawać miała pod opieką stryja.

\section{Jan Magnus Tęczyński, wojewoda krakowski}

Jan Magnus Tęczyński, najmłodszy z braci, urodził się 16/17 września 1579 r. w Kraśniku. Po śmierci Andrzeja i Gabriela był jedynym dorosłym przedstawicielem swojego rodu. Przed 22 grudnia 1605 r. otrzymał urząd podczaszego królowej i pełnił go aż do uzyskania nominacji senatorskiej. 31 sierpnia 1620 r. został wojewodą krakowskim. W czerwcu 1606 r. ożenił się z Dorotą Mińską herbu Prus III († po 1646), córką podkanclerzego koronnego Stanisława († 1607) i Urszuli Dembińskiej herbu Rawicz, kasztelanki krakowskiej. 28 czerwca 1606 r. otrzymał od teścia cesję grodowego starostwa płockiego. Tego samego dnia zawarł kilka umów ze Stanisławem Mińskim oraz jego matką, Dorotą z Ojrzanowa Goryńską $1^{\circ} \mathrm{v}$. Mińską, $2^{\circ} \mathrm{v}$. Barziną. W ramach posagu żony, jej babka - wojewodzina krakowska Barzina zastawiła Tęczyńskiemu w kwocie 30 tys. florenów swoje własne wsie dziedziczne Dobrów, Marszewa, Skrzyszewo Małe i Skrzyszewo Wielkie w województwie łęczyckim. On zaś „oprawił” Dorocie z Mińskich 40 tys. florenów posagu i drugie tyle wiana na połowie wszystkich swoich dóbr. 29 lipca 1609 r. małżonkowie Tęczyńscy zeznali w grodzie krakowskim zapis wzajemnego dożywocia na wszystkich swoich dobrach ${ }^{52}$.

51 SGKP, t. 12, Warszawa 1892, s. 400; J. Kurtyka, op. cit., s. 226.

52 W. Urban, op. cit., s. 93-94; A. Kłodziński, op. cit., szp. 242; W. Dworzaczek, Genealogia, t. 2, tabl. 94; Urzędnicy, t. 4, z. 2, nr 413; S. Gruszecki, Miński Stanisław, PSB, 
W czerwcu 1606 r. Jan Magnus Tęczyński otrzymał starostwo płockie. W skład tej królewszczyzny wchodziły miasta Płock i Bielsk oraz wsie Cekanów, Chełpowo, Draganie, Dziarnowo, Powsin, Troszyn, Winiary i Wykowo. 12 marca 1614 r. uzyskał konsens królewski na cesję tego starostwa na rzecz Ludwika Krasińskiego. Ustąpił z tej królewszczyzny jednak dopiero w 1617 r. W tym samym roku przejął po bracie Gabrielu dzierżawę Uścieczko (1 miasto i około 20 wsi), z której zrezygnował na rzecz wojewody bracławskiego Stefana Potockiego i jego żony, Marii z Mohyłów w 1631 r. W 1622 r. Tęczyński dostał nadanie starostwa radoszyckiego w powiecie chęcińskim w województwie sandomierskim (miasto Radoszyce, wsie Cisownik, Przyłogi, Radoska albo Przedmieście, Wola Dzibałtowska i Wola Kamienna). Z dzierżawy tej ustąpił jednak już w roku następnym na rzecz zaprzyjaźnionego z nim Jerzego Ossolińskiego, późniejszego kanclerza wielkiego koronnego. Krótko użytkował również starostwo żarnowieckie w województwie krakowskim (miasto Żarnowiec, wsie Chlina, Czubrowice, Jeżówka, Kąpiele, Koryciany, Łany Małe, Łany Wielkie, Otola, Przybysławice, Wierzbica, Wola Libertowska, Żędowice alias Rzędowice), które otrzymał po śmierci kasztelana krakowskiego Jerzego ks. Zbaraskiego w 1631 r. Już w roku 1633 odstąpił tę królewszczyznę burgrabiemu krakowskiemu Marcinowi Wybranowskiemu. Warto również pamiętać o tym, że od chwili swojej nominacji aż do śmierci Jan Magnus Tęczyński użytkował dobra krzesłowe wojewodów krakowskich, a więc wsie Dobraków, Dobrogoszczyce, Kroczyce, Krzywopłoty, Podlesice (część), Siemieszyce (część) i Zętkowice alias Rzędkowice. W sumie zatem, w różnych okresach swojego życia wojewoda krakowski czerpał dochody z 5 miast i ponad 50 wsi królewskich.

t. 21, Wrocław 1976, s. 322. Dodajmy w tym miejscu, że umowę przedmałżeńską zawarł Jan Tęczyński, tytułowany już wówczas podczaszym królowej, ze Stanisławem Mińskim w grudniu 1605 r. pod zakładem 80 tys. florenów. Por. „Stanislaus Miński et Joannes Tęczyński roborant intercisam", AGAD, MK 150, k. 284-285. 28 czerwca 1606 r. małżonkowie Jan i Dorota Tęczyńscy skwitowali Dorotę z Ojrzanowa Barzinę z 22 tys. florenów i potwierdzili zastaw Mińska dokonany przez podkanclerzego koronnego na rzecz Marcina Leśniowolskiego. Por. „Joannes Tęczyński et Dorothea Mińska Palatinae Cracoviensis quietant", AGAD, MK 152, k. 19-20v. Ponadto w tym samym tomie Metryki Koronnej zarejestrowano następujące transakcje: „Dorothea Barzina de Ojrzanów Joanni Tęczyński bona sua hereditaria [--] modo obligatorio inscribit", ibidem, k. 20v.-22 (zastaw na rzecz J. Tęczyńskiego czterech wsi w województwie łęczyckim); „Stanislaus Miński Joanni Tęczyński Capitaneatus Plocensis cedit”, ibidem, k. 22-22v. (S. Miński ceduje na rzecz J. Tęczyńskiego starostwo płockie); „Joannes Tęczyński Dorothea Mińska consorti sua reformatione inscribit”, ibidem, k. 24-25 (Jan Tęczyński oprawia Dorocie z Mińskich podwójną sumę posagu w kwocie 80 tys. florenów na połowie swoich dóbr). Por. też Dożywocie Jana i Doroty z Mińskich Tęczyńskich, ANK, CCI 190, s. 243-245. 
Należy też podkreślić fakt, że każda rezygnacja z posiadanej przez niego królewszczyzny wiązała się z otrzymaniem stosownego ekwiwalentu w gotówce od jej nowego nabywcy ${ }^{53}$.

Po śmierci starszych braci Jan Magnus Tęczyński podjął próbę scalenia wszystkich dóbr rodowych w swoim ręku. Jak już wspomniano, po śmierci Elżbiety z Radziwiłłów dokonał zajazdu dóbr międzyrzeckich, usuwając z nich drugiego męża bratowej, Krzysztofa Kiszkę. Pozyskanym w ten sposób kluczem osad skupionych wokół Międzyrzeca (1 miasto, 45 wsi, 11 folwarków) dysponował aż do śmierci. Stopniowo przejmował również dobra pozostałe po średnim bracie i dwójce jego młodo zmarłych dzieci. Istotną przeszkodą był w tym przypadku fakt, że na połowie dóbr kasztelana bełskiego Andrzeja wdowa po nim miała zabezpieczoną oprawę w wysokości 120 tys. florenów. Z pewnością też Katarzyna z Leszna zatrzymała w swoim ręku przynajmniej część majętności swojego pierwszego małżonka. Dopiero po zaspokojeniu jej pretensji, co nastąpiło w latach 1620-1623, Jan Magnus wszedł w realne posiadanie (formalnie w imieniu własnym oraz bratanicy Zofii) tych majątków rodowych, które w 1601 r. przypadły na schedę Andrzeja ${ }^{54}$.

Z całą pewnością wojewoda krakowski objął w spadku po średnim bracie dobra w województwie sandomierskim z Rytwianami, Staszowem i Łubnicami (1 miasto, 33 wsie, 9 folwarków). Trzymał również majętność toporowsko-stołpińską (1 miasto, 9 wsi, 1 folwark) w województwie

${ }^{53}$ K. Chłapowski, Starostowie, s. 129, 135, 173; Konsens królewski na wykupienie dóbr Uścieczko przez Jana Tęczyńskiego od spadkobierców jego brata Gabriela, AGAD, MK 161, k. 168-169; Lustracja starostwa płockiego, MK, Lustracje, dz. XVIII, nr 64, s. 64-65 ; J. Kurtyka, op. cit., s. 210; Księga wpisów kancelarii koronnej podkanclerzego Tomasza Zamoyskiego z lat 1628-1635 ze zbiorów sztokholmskiego Riksarkivet sygnatura Skokloster E[nskilda] 8636), oprac. W. Krawczuk, Kraków 1999 (Sumariusz Metryki Koronnej, t. 1), nr 119 (Jan Tęczyński rezygnuje z dzierżawy Uścieczko na rzecz Stefana Potockiego i jego żony, Marii z Mohyłów); SGKP, t. 9, Warszawa 1888, s. 442; J. Ossoliński, Pamiętnik, oprac. W. Czapliński, Warszawa 1976, s. 89; Województwo krakowskie w drugiej połowie XVI wieku, cz. 2: Komentarz, indeksy, red. H. Rutkowski, oprac. K. Chłapowski [et al.], Warszawa 2008 (Atlas historyczny Polski. Mapy szczegółowe XVI wieku, 1), s. 96, 99.

${ }^{54}$ BK, TD, GiZ, Poznań, Inskrypcje, XVII wiek, 4124 (Nr. 1004), 1620 (Katarzyna z Leszna kasuje zapisy Andrzeja Tęczyńskiego na sumę 100 tys. florenów na połowie jego dóbr); Poznań, Rezygnacje, XVII wiek, Część 1, 7834 (Nr. 1412), 1620 (Katarzyna z Leszna kwituje Jana Tęczyńskiego z 30 tys. florenów oprawy na włości rytwiańskiej); 3010 (Nr. 1414), 1623 (Katarzyna z Leszna kwituje Jana Tęczyńskiego z 90 tys. florenów należnych jej z zapisów pierwszego męża). Por. też „Comes a Tenczyn Czarnkowskiej Palatinae Lancicensis intercisam roborat”, ANK, CCI 215, s. 2300-2303; „Comes a Tenczyn Palatinae Lancicensis intercisam roborat", ibidem, s. 2569-2572 (umowy zawarte przez J. Tęczyńskiego z małżonkami Czarnkowskimi - pierwsza po zakładem 110 tys., druga zaś 100 tys. florenów). 
ruskim. Nie udało mu się natomiast przejąć Jakubowic w województwie lubelskim. Po śmierci Andrzeja Tęczyńskiego jego starszy brat Gabriel, sprawujący opiekę nad dziećmi kasztelana bełskiego zastawił bowiem te dobra (lub też sprzedał z prawem odkupu) stolnikowi gostynińskiemu Feliksowi Gorzewskiemu. Ten z kolei sprzedał Jakubowice, Długie (część), Rudniczek, Świdniczek i Świdnicką Wolę kasztelanowi krakowskiemu Januszowi ks. Ostrogskiemu. Ten ostatni już w 1616 r. występował jako właściciel Jakubowic z przyległościami. Przez kilka następnych lat zarówno Jan Magnus Tęczyński, występujący w imieniu własnym, bratanicy i czwórki swoich dzieci, jak też Katarzyna z Leszna Czarnkowska usiłowali doprowadzić do unieważnienia tej transakcji. Wszystkie ich zabiegi spełzły jednak na niczym i kasztelan krakowski utrzymał się ostatecznie w posesji spornych dóbr ${ }^{55}$. Tęczyńscy nie zatrzymali również w swoich rękach wsi Stawce, Studzianki i Wola Studzieńska w województwie lubelskim. W rejestrze poborowym z 1626 r. w żadnej z tych wsi nie odnotowano bowiem ich własności. Nie wydaje się również, aby Jan Magnus starał się utrzymać w swoim posiadaniu wsie Chochłów, Honiatycze i Hulcze w województwie bełskim. W każdym razie, żadna z tych wsi nie znalazła się w spisie dóbr jego spadkobierców w drugiej połowie XVII w. W 1621 r. Jan Magnus Tęczyński uszczuplił też nieco swój stan posiadania we włości rytwiańsko-łubnickiej. Wsie Sieragi (z folwarkiem), Wolicę i Zrębin darował bowiem ufundowanemu przez siebie eremowi kamedułów św. Romulada w Rytwianach ${ }^{56}$. Ostatecznie więc, po przejęciu schedy po średnim bracie i uporządkowaniu wszystkich spraw majątkowych związanych z objęciem spadku, dobra wojewody krakowskiego powiększyły się o 2 miasta, 39 wsi i 9 folwarków.

Jak już wspomniano, od śmierci brata Gabriela Jan Magnus Tęczyński sprawował opiekę nad jego córką Zofią. W jej imieniu zarządzał włością krasiejowską w województwie ruskim. Tęczyńscy stopniowo wyzbywali się jednak kolejnych wiosek z tego majątku. Jeszcze w 1621 r. odnotowano w ich rękach wsie Peczeniżyn i Rungury. Wydaje się jednak, że wsie

55 „Famulorum Illustris et Magnifici Janussi Ducis ab Ostróg Castellani Cracoviensis relatio”, AP w Lublinie, LGR, nr 46, k. 128v.-129; „Czarnkowska protestatio”, LGR, nr 48, k. 330v.-331; "Janussi Ducis ab Ostróg protestatio”, LGR, nr 49, k. 640v.-642v.; „Castellani Cracoviensis denegata intromissio”, ibidem, k. 885v.-888; „Magnifica Cathernia a Leszno protestatio”, ibidem, k. 1000v.; „Castellani Cracoviensis rumatio”, ibidem, k. 1004-1005; „Castellanus Cracoviensis contumax”, LZS, nr 62, k. 516-516v.

${ }^{56}$ Rejestr lubelski 1626, s. 78-79 (właścicielem wszystkich trzech wsi był wówczas Jerzy Drzewicki). Informacje o właścicielach wspomnianych tu wiosek w województwie bełskim w drugiej połowie XVII w. por. W. Bondyra, Własność ziemska w województwie bełskim w czasach saskich, Lublin 2015, s. 98, 109; SGKP, t. 10, s. 119. 
te (wraz z innymi, jeśli jeszcze jakieś pozostawały wówczas we władaniu panów na Tęczynie) zostały sprzedane Potockim w roku 1631, kiedy to wojewoda krakowski zrezygnował na ich rzecz z dzierżawy Uścieczko. Nieprzerwanie $\mathrm{w}$ formalnym posiadaniu bratanicy Jana Magnusa (faktycznie zaś jego samego) pozostawały natomiast dobra Sowoklęski w województwie lubelskim $^{57}$. W pierwszym kwartale 1627 r. Jan Magnus Tęczyński pozyskał wreszcie Końskowolę z przyległościami, spłacając koniuszego koronnego Krzysztofa ks. Zbaraskiego, który trzymał te dobra jedynie prawem zastawnym w kwocie 153 tys. florenów. Transakcja ta została przeprowadzona krótko przed śmiercią księcia Krzysztofa, który szykując się do opuszczenia wykupionego przez wojewodę krakowskiego majątku, zmarł w Końskowoli 6 marca 1627 r. ${ }^{58}$ Po pozyskaniu dóbr końskowolskich, Jan Magnus Tęczyński powiększył swój stan posiadania o 1 miasto, 22 wsie i 9 folwarków. Jeśli zaś uwzględnimy klucz międzyrzecki oraz Sowoklęski to okaże się, że z dóbr należących niegdyś do wojewody lubelskiego Gabriela najmłodszy z braci Tęczyńskich przejął ostatecznie 2 miasta, 70 wsi i 20 folwarków.

Jan Magnus Tęczyński przeprowadził również kilka transakcji dotyczących wiosek wchodzących w skład jego własnego działu. Już w czerwcu 1601 r. dokonał rozliczenia z administratorami swoich dóbr

57 W. Łoziński, op. cit., t. 1: Czasy i ludzie, s. 196 (tu informacje o Peczeniżynie i Rungurach). Gwoli wyjaśnienia dodajmy, że Sowoklęski były obciążone dość znacznymi długami zaciągniętymi tak przez Andrzeja Ożarowskiego (3 tys. florenów), jak i przez Gabriela Tęczyńskiego (9 tys. florenów). Z tego powodu Tęczyńscy prowadzili kilka procesów z wierzycielami, głównie z Ożarowskimi i Glinieckimi. Procesowali się także z sąsiadem Sowoklęsk - Abrahamem Sieniutą. Por. „Tęczyńskich protestatio”, AP w Lublinie, LGR, nr 49, k. 241-241v.; „Comitis in Tenczyn Palatini Cracoviensis intromissio”, LGR, nr 55, k. 914-916; „Tęczyńska Palatina Lublinensis subdito Sieniuta administrabit”, LZS, nr 62, k. 820-821v.; „Inter Ożarowski et Tęczyńska motio”, ibidem, k. 1030-1032; „Inter Tęczyńska et Sieniuta motio”, LZS, nr 63, k. 260v.-262; Rejestr lubelski 1626, s. 2021 (tu Jan Tęczyński odnotowany jako właściciel wsi Sowoklęski i Wola Serowa).

58 „Palatinus Cracoviensis sorori sua cedit”, ANK, CCI 245, s. 1107-1114 (tu wzmianka o tym, że Jan Tęczyński pozyskał klucz końskowolski od Krzysztofa ks. Zbaraskiego. Musiał zatem wykupić Końskowolę jeszcze za życia księcia koniuszego); „Idem eidem roborat”, ibidem, s. 1114-1116; „Idem eidem tenetur”, ibidem, s. 1116-1118. Dodajmy w tym miejscu, że jeszcze w pierwszych tygodniach 1627 r. Krzysztof ks. Zbaraski, zastawny posesor tych dóbr, był pozywany przez plebana z Gołębia o dziesięcinę ze wsi Młynki, Opoka i Osiny. Por. „Dux a Zbaraż contumax”, AP w Lublinie, LZS, nr 65, k. 116. Rozliczenia z tym plebanem dokonał już jednak wojewoda krakowski, który uzyskał od niego skwitowanie z wszelkich pretensji. Por. „Palatinus Cracoviensis quittatur”, LZWZ, nr 110, k. 874-874v. Por. też R. Szczygieł, Od lokacji do upadku szlacheckiej Rzeczypospolitej, w: Dzieje Końskowoli, red. idem, Lublin 1988, s. 42; oraz Z. Anusik, Dobra ziemskie Tęczyńskich, s. 208-209 (tu błędnie o okolicznościach pozyskania przez Jana Tęczyńskiego klucza końskowolskiego); idem, Dwa ostatnie pokolenia, s. 737-738. 
podkrakowskich. Krzysztof Falęcki otrzymał wówczas donację połowy wsi Strzeszkowice w województwie lubelskim, a Jan Piotraszowski (naturalny syn kasztelana wojnickiego Jana Tęczyńskiego) z racji należnej mu sumy 5 tys. florenów wziął w zastaw Czyżówkę, Myślachowice z folwarkiem, Sierszę i Wodną. Paweł Rudawski został z kolei skwitowany z zarządu dóbr Maciejów i Giebułtów ${ }^{59} .26$ listopada 1614 r. Dorota z Mińskich Tęczyńska scedowała na swojego męża kwotę 50 tys. florenów zabezpieczonych na wsiach Cierpięta, Janówek, Wierzbno, Wyględów i Zimna Woda w województwie mazowieckim, powiecie liwskim, które otrzymała w spadku po swojej babce, wojewodzinie krakowskiej Dorocie z Ojrzanowa Barzinej ${ }^{60}$. W nieznanym bliżej czasie Tęczyńscy odsprzedali jednak te dobra. Wyzbyli się również trzymanych od 1606 r. wiosek w województwie łęczyckim. 27 stycznia 1624 r. Jan Magnus Tęczyński zarejestrował w grodzie krakowskim cały szereg transakcji majątkowych. Sprzedał wówczas na wyderkaf za 8 tys. florenów Zofii z Maciejowskich, wdowie po Janie Czerskim, Grodziec z folwarkiem i Zalas. Na podobnych warunkach wydał za 18 tys. florenów Katarzynie z Kretkowskich, wdowie po Adamie Ligęzie, Bachowice $\mathrm{z}$ folwarkiem oraz Grodzisko $\mathrm{z}$ folwarkiem. Pożyczył 10 tys. florenów od Stanisława Stadnickiego, 6600 florenów od Piotra Brzechffy i 6 tys. florenów od Krzysztofa Soleckiego. Mikołajowi Wizembergowi darował (w istocie zaś sprzedał za 3 tys. florenów) Obrazowice z folwarkiem. Został też skwitowany z 4 tys. florenów stanowiących część wcześniejszej pożyczki w wysokości 40 tys. florenów zaciągniętej u Jana Korycińskiego, w której to kwocie ten ostatni trzymał w zastawie miasto Nową Górę ${ }^{61}$.

W świetle rejestru poborowego województwa krakowskiego z $1629 \mathrm{r}$. Jan Magnus Tęczyński był właścicielem miasta Nowa Góra oraz wsi Baczyn (część), Brzoskwinia, Cholerzyn, Chrosna (część), Czermna (Czerna),

59 „Joannes comes in Tenczyn Christophero Falęcki donat”, ANK, CCI 172, s. 14951500; „Idem comes in Tenczyn et Piotraszowski intercisam roborant”, ibidem, s. 15001502; „Idem comes in Tenczyn et Rudawski intercisam roborant”, ibidem, s. 1502-1504; „Idem comes in Tenczyn Joanni Piotraszowski obligat”, ibidem, s. 1504-1508; J. Kurtyka, op. cit., s. 148. Dodajmy w tym miejscu, że cesja Strzeszkowic oznaczała trwałe wypadnięcie tej wioski ze składu latyfundium Tęczyńskich. Por. Rejestr lubelski 1626, s. 35-36, 61.

60 „Dorothea Tęczyńska marito suo cedit”, ANK, CCI 200, s. 2068-2070. Por. też I. Kotowa, Barzina z Ojrzanowa Dorota, PSB, t. 1, Kraków 1935, s. 346.

61 „Palatinus Cracoviensis Zofia Czeska vendit”, ANK, CCI 220, s. 2632-2637; „Idem Ligęzinej vendit”, ibidem, s. 2637-2642; „Idem Stadnickiemu tenetur”, ibidem, s. 26422644; „Idem Brzechffie tenetur”, ibidem, s. 2644-2646; „Idem Soleckiemu tenetur”, ibidem, s. 2646-2648; „Idem Wizembergowi roborat recognitionem”, ibidem, s. 2648-2651; „Koryciński Palatini Cracoviensis quietat”, ibidem, s. 2651-2652; „Comes in Tenczyn Palatinus Cracoviensis Wizembergowi donat", ibidem, s. 2656-2660. 
Czyżówka, Filipowice, Frywałd, Grodziec, Kępa, Krzeszowice, Miękinia, Młynka, Morawica (część), Myślachowice, Nawojowa Góra, Nielepice (część), Ostrożnica (część), Rudno, Siersza, Tenczynek, Wodna i Zalas oraz leżących poza kompleksem dóbr tęczyńskich Jankowic (część) i Obrazowic (Obrażejowic). Nowym nabytkiem wojewody krakowskiego była wieś Psary w parafii Płoki. Miał on również Bachowice i Grodzisko w powiecie śląskim (nieobjętym rejestrem). W składzie klucza wsi skupionych wokół zamku w Tęczynie w roku 1629 nie wymieniono Woli Filipowskiej i Wólki, które w tym czasie przestały już istnieć, oraz Prądnika z młynem Hanesz, który został przez Tęczyńskiego sprzedany. Wojewoda krakowski wyzbył się również wsi Giebułtów z folwarkiem, Maciejów, Małoszów i Tuchołów, które kupił od niego Piotr Szyszkowski, późniejszy kasztelan wojnicki. Jako własność Tęczyńskiego oznaczono natomiast dobra krzesłowe użytkowane przez niego z racji pełnienia urzędu wojewody krakowskiego oraz kilka wsi, które kupił z przeznaczeniem na uposażenie ufundowanego przez jego siostrę, Agnieszkę Firlejową klasztoru Karmelitów w Czermnej (Czernej) ${ }^{62}$. W latach trzydziestych XVII w. (po przekazaniu owych wsi zakonnikom) Jan Magnus Tęczyński miał więc w województwie krakowskim 1 miasto, 22 wsie całe, 6 części wsi i 14 folwarków. Były to jedyne dobra z działu przeprowadzonego w 1601 r., które zachował w swoim ręku. Oprócz połowy Strzeszkowic w województwie lubelskim wyzbył się bowiem również majętności przewodowskiej w województwie bełskim, która przeszła w ręce strażnika koronnego Samuela Łaszcza ${ }^{63}$. Nie miało to jednak większego wpływu na sytuację majątkową wojewody krakowskiego. U schyłku życia władał on bowiem latyfundium, które obejmowało 5 miast, 137 wsi i części wsi oraz 43 folwarki.

W małżeństwie z Dorotą z Mińskich Jan Magnus Tęczyński miał trzech synów - Gabriela, Krzysztofa i Stanisława oraz córkę Izabelę. Najstarszy z rodzeństwa, Gabriel, urodzony około 1607 r. zginął w 1629 r. w pojedynku w Lowanium, gdzie przebywał na studiach. Drugi syn, Krzysztof,

${ }^{62}$ Rejestr poborowy województwa krakowskiego z roku 1629, oprac. W. Domin [et al.], red. S. Inglot, Wrocław 1956, s. 5-6, 30, 32-34, 37-41, 95, 120-121, 125, 127, 157, 167, 173-174, 186. Gwoli wyjaśnienia dodajmy, że w grudniu 1626 r. podwojewodzi krakowski Wojciech Miroszowski kupił za 45 tys. florenów (wyłożonych przez Agnieszkę Firlejową) od mieszczanina krakowskiego Melchiora Gerstmana wsie Siedlec, Paczółtowice, Żbik oraz część Dubia i część Żar (wszystkie te wsie, poza Siedlcem, wymieniono w rejestrze jako własność Tęczyńskiego). W dwóch aktach z 1627 i 1628 r. Miroszowski odstąpił z kolei te wsie Janowi Magnusowi Tęczyńskiemu, a ten w kwietniu 1630 r. przekazał je klasztorowi Karmelitów św. Michała w Krakowie jako macierzy powstającego właśnie klasztoru w Czermnej (Czernej). Por. J. Kurtyka, op. cit., s. 155-156.

${ }^{63}$ W. Bondyra, op. cit., s. 101. 
urodzony 29 marca 1609 r., został zabity w lipcu 1632 r. w Gaecie koło Sermonety, kiedy wtargnął samowolnie do chłopskiej winnicy i wdał się w bójkę z jej właścicielami. Został pochowany w klasztorze Kamedułów w Tusculum. Trzeci, najmłodszy z braci Tęczyńskich, Stanisław, urodzony 19 września 1611 r., zmarł w początkach listopada 1634 r. w obozie wojskowym pod Kamieńcem Podolskim. 10 listopada mowę przy wyprowadzeniu jego ciała wygłosił Jakub Sobieski. Zwłoki Stanisława Tęczyńskiego zostały przewiezione do Rytwian, gdzie spoczęły w podziemiach ufundowanego przez jego ojca klasztoru Kamedułów. Żaden z młodych Tęczyńskich nie zdążył odegrać jakiejkolwiek roli na scenie politycznej6 ${ }^{64}$ Jedynym dzieckiem, które przeżyło ojca, była córka Izabela.

W ostatnich latach swego życia Jan Magnus Tęczyński energicznie prowadził zapoczątkowaną aktem fundacyjnym z 1617 r., a rozpoczętą w 1621 r. budowę klasztoru Kamedułów w Rytwianach. Późną wiosną 1637 r. podjął decyzję o odbyciu planowanej od dawna pielgrzymki do Loreto i zaczął w tym celu gromadzić potrzebne fundusze. 16 czerwca pożyczył 30 tys. florenów od podczaszego bracławskiego Jakuba Żeleńskiego z Żelanki i roborował z nim umowę pod zakładem 20 tys. florenów. Scedował podwojewodziemu krakowskiemu Wojciechowi Miroszowskiemu swoje prawa do stawów koło Barwałdu i Wadowic w starostwie zatorskim. Klasztorowi Kamedułów w Rytwianach zapisał na wypadek swojej śmierci czynsz roczny 4 tys. florenów z kopalni galmanu w dobrach tęczyńskich. Zgodnie z wolą wojewody erem rytwiański pobierać miał również 600 florenów rocznego czynszu wyderkafowego ze wsi Szczeka. Tego samego dnia Jan Magnus ustanowił opiekunów dla niezamężnej siostry Izabeli, swojej córki o tym samym imieniu oraz bratanicy Zofii. Zostali nimi żona Tęczyńskiego, Dorota z Mińskich, kanclerz wielki koronny Tomasz Zamoyski oraz siostra wojewody, Agnieszka z Tęczyńskich Firlejowa ${ }^{65}$.

${ }^{64}$ W. Dworzaczek, Genealogia, t. 2, tabl. 94; A. Kłodziński, op. cit., szp. 244, 253; J. Kurtyka, op. cit., s. 214-215; A.S. Radziwiłł, op. cit., t. 2, s. 249-250; A. Sajkowski, Włoskie przygody Polaków. Wiek XVI-XVIII, Warszawa 1973, s. 246-251; M. Barłowska, „Bo przystoi by mężne tak wieziono ciała”. Mowy przy wyprowadzaniu ciała rycerza z obozu, „Wschodni Rocznik Humanistyczny" 7, 2010, s. 62-63; Mowa na wyprowadzeniu ciała Jego M[oś]ci Pana Stanisława Tęczyńskiego, wojewodzica krakowskiego, z Kamieńca 10 Novembris Anno 1634, przez Jego M[oś]ć Pana Jakuba Sobieskiego, krajczego koronnego, w: J. Sobieski, Mowy pogrzebowe, wyd. M. Barłowska, M. Ciszewska, Warszawa 2019, s. 95-97; Fontes Lublinenses, t. 9: Miscellanea Lublinensia. Raptularz Zbigniewa Borowskiego z lat 1604-1644. Taksa cen towarów sporzadzona przez komisję sejmowa w Lublinie w 1628 r., oprac. H. Gmiterek, Lublin 2017, s. 43-44 (tu informacja o przewiezieniu ciała młodego Tęczyńskiego do Rytwian).

65 „Palatinus Cracoviensis Żeleńskiemu tenetur”, ANK, CCI 245, s. 883-884; „Idem Palatinus Cracoviensis eidem roborat”, ibidem, s. 884-886; „Idem Palatinus Cracoviensis 
Dwa tygodnie później (1 lipca 1637 r.) Jan Magnus Tęczyński wniósł do grodu krakowskiego zeznanie o odstąpieniu Agnieszce Firlejowej zastawu na dobrach końskowolskich. Formalnie rzecz biorąc, wojewodzina krakowska powinna mu przekazać 153 tys. florenów, ponieważ jednak strony roborowały tę umowę pod zakładem 170 tys. florenów, mogło to oznaczać, że Firlejowa dała bratu taką właśnie sumę. Jednocześnie Tęczyński zeznał, że jest winien siostrze 70 tys. florenów, które obiecywał spłacić do 24 czerwca roku następnego ${ }^{66}$. Zgromadziwszy odpowiednie środki, wojewoda krakowski rozpoczął przygotowania do podróży. Nie zdążył jednak opuścić kraju. Zmarł 17 lipca 1637 r. w Rytwianach i został pochowany w ufundowanym tam przez siebie klasztorze Kamedułów ${ }^{67}$. Był ostatnim męskim potomkiem rodu Tęczyńskich.

\section{Zofia z Tęczyńskich Daniłowiczowa, podskarbina wielka koronna}

Śmierć wojewody krakowskiego rozpoczęła nowy rozdział w dziejach latyfundium rodu Tęczyńskich. Jak już wcześniej wspomniano, na wieść o zgonie Jana Magnusa wuj Zofii, Aleksander Ludwik ks. Radziwiłł, nie

Firlejowej recognitionem roborat”, ibidem, s. 888-895; „Idem Palatinus Cracoviensis tutores constituit", ibidem, s. 900-901. Dodajmy, że wspomniana tu Izabela Tęczyńska była trzecią córką wojewody krakowskiego Andrzeja i Zofii z Dembowskich. Urodziła się około 1585 r. Nigdy nie wyszła za mąż, a życie spędziła na dewocji przy kościele Jezuitów w Lublinie. Pozostawała pod opieką braci. Zmarła w Lublinie w 1645 r. i została pochowana w tamtejszym kościele Jezuitów. W cytowanej przez Kaspra Niesieckiego inskrypcji nagrobnej odnotowano, że przeżyła 60 lat. Por. A. Kłodziński, op. cit., szp. 242-243; J. Kurtyka, op. cit., s. 212; K. Niesiecki, op. cit., t. 9, s. 65-66.

66 „Palatinus Cracoviensis sorori sua cedit”, ANK, CCI 245, s. 1107-1114; „Idem eidem roborat”, ibidem, s. 1114-1116; „Idem eidem tenetur”, ibidem, s. 1116-1118. Dodajmy w tym miejscu, że Tęczyński scedował również na siostrę prawo do wykupienia z zastawu wsi Osiny (wraz z Wolą Osińską, Wolą Profecińską i Wronowem), które to wsie on sam zastawił 14 sierpnia $1634 \mathrm{r}$. w Lublinie staroście chełmskiemu Hieronimowi Jełowickiemu, oraz wsi Nowodwór, którą jeszcze Krzysztof ks. Zbaraski zastawił 25 października 1622 r. Wojciechowi Mackiewiczowi. Por. „Idem eidem cedit”, ibidem, s. 1118-1119; oraz „Subditi Illustris et Magnifici Palatinus Cracoviensis manifestatur”, AP w Lublinie, LGR, nr 66, k. 125v.-127v.; „[Post mortem] Illustris et Magnificus comes in Tenczyn Palatina Cracovienisi intromissio", LGR, nr 67, k. 545-545v. (tu m.in. informacja, że Firlejowa przejęła zastaw za 153 tys. florenów oraz że objęła dobra końskowolskie w realne posiadanie).

${ }^{67}$ A. Kłodziński, op. cit., szp. 253-254, 257-258; J. Kurtyka, op. cit., s. 210-211; Z. Anusik, Dobra ziemskie Tęczyńskich, s. 209-212; A. Sajkowski, Włoskie przygody, s. 50-51; Urzędnicy, t. 4, z. 2, nr 413. 
uznając ważności zapisu na rzecz brata dokonanego w 1617 r. przez Gabriela Tęczyńskiego, zajechał dobra międzyrzeckie ${ }^{68}$. Postępowanie Radziwiłła spowodowane było troską o interesy siostrzenicy, nad którą właśnie przejął on opiekę. W tym ostatnim przypadku Radziwiłł działał zresztą zgodnie z przepisami prawa, gdyż Jan Magnus Tęczyński, sam będąc tylko opiekunem Zofii, nie mógł wyznaczyć jej nowych opiekunów. Zajazd dóbr międzyrzeckich zapoczątkował ciągnące się przez wiele lat spory o majątek rodowy Tęczyńskich. Stronami walczącymi o dobra, które pozostawił po sobie wojewoda krakowski, były dwie siostry stryjeczne - Zofia, córka Gabriela i Izabela, córka Jana. Wbrew pozorom, w lepszej sytuacji była ta pierwsza. Na jej korzyść działało prawo oraz poparcie ze strony wpływowego wuja. Sprzyjały jej również inne okoliczności - szybka śmierć jednego z opiekunów Izabeli, kanclerza wielkiego koronnego Tomasza Zamoyskiego, który zmarł już 8 stycznia 1638 r. oraz ambiwalentna postawa drugiej opiekunki - wojewodziny krakowskiej Agnieszki Tęczyńskiej.

Odzyskawszy możliwość swobodnego dysponowania własną osobą, w początkach $1638 \mathrm{r}$. Zofia Tęczyńska wyszła za mąż za podskarbiego wielkiego koronnego Jana Mikołaja Daniłowicza (*ok. 1602 † 1650). 20 lutego tego roku w grodzie krakowskim małżonkowie zeznali zapis wzajemnego dożywocia na wszystkich dobrach ruchomych i nieruchomych ${ }^{69}$. Wkrótce po ślubie przejęli też od Aleksandra Ludwika ks. Radziwiłła dobra międzyrzeckie (1 miasto, 45 wsi i 11 folwarków). 29 marca 1638 r. podskarbi Daniłowicz uzyskał dla Zofii ius communicativum na starostwach ratneńskim i błońskim. 30 maja tego roku król wyraził zgodę na objęcie dożywociem Zofii z Tęczyna Daniłowiczowej również wsi królewskich Dryszczów, Depułtycze, Mołodutyn, Roztoka i Żmudź w ziemi chełmskiej ${ }^{70}$.

${ }^{68}$ A.S. Radziwiłł, op. cit., t. 2, s. 249-250.

69 „Daniłowiczów coniugum advitalitas”, ANK, CCI 246, s. 693-694 (zapis wzajemnego dożywocia Jana Daniłowicza i Zofii Tęczyńskiej). Warto w tym miejscu zaznaczyć, że twierdzenie Wojciecha Hejnosza, jakoby Jan Mikołaj Daniłowicz urodził się około 1607 r., jest nieprawdziwe. Por. W. Hejnosz, Daniłowicz Jan Mikołaj, PSB, t. 4, Kraków 1938, s. 415. W rzeczywistości był on bowiem przynajmniej pięć lat starszy. Por. niżej przyp. 79.

70 „Communicatio iuris Magnifica Zophia a Tenczyn coniugi Magnifici Joanni Nicolai Daniłowicz Supremi Regni Thesaurarii super Capitaneatus Ratnensis”, AGAD, MK 185, k. 14-15; „Eidem communicatio iuris super Capitaneatus Blonensis”, ibidem, k. 15-16; „Communicatio iuris Magnifica Zophia a Tenczyn, coniugi Magnifici Joanni Nicolai Daniłowicz Supremi Thesaurarii Regni super villas Żmudź et Dryszów", ibidem, k. 84v.-86v. Dodajmy w tym miejscu, że Dryszczów (w przywileju królewskim nazwany Dryszowem) wraz z czterema pozostałymi wioskami stanowił tenutę wydzieloną ze starostwa grodowego chełmskiego. Warto również zaznaczyć, że Błonie, Ratno i Dryszczów 
W 1640 r. Jan Mikołaj i Zofia weszli w posiadanie Końskowoli (1 miasto, 22 wsie, 9 folwarków), co oznacza, że właśnie wtedy wykupili te dobra z zastawu wojewodziny krakowskiej Agnieszki z Tęczyna Firlejowej ${ }^{71}$. W owym czasie Daniłowiczowie prowadzili już zaciekłe spory majątkowe z córką Jana Magnusa Tęczyńskiego Izabelą i jej mężem (od 28 listopada 1639 r.), starostą pobiedziskim Łukaszem z Bnina Opalińskim, przyszłym podkomorzym poznańskim, a następnie marszałkiem nadwornym koronnym. Opalińscy dążyli bowiem do odzyskania Międzyrzeca i Końskowoli, a Daniłowiczowie żądali oddania im Sowoklęsk (dziedzicznych dóbr Zofii) oraz połowy dóbr po kasztelanie bełskim Andrzeju Tęczyńskim (w tym przypadku chodziło o dobra w województwie sandomierskim oraz klucz toporowski w województwie ruskim $)^{72}$.

W 1644 r. Jan Mikołaj Daniłowicz za zgodą i zezwoleniem żony sprzedał połowę spornych dóbr toporowskich w powiecie lwowskim kasztelanowi krakowskiemu i hetmanowi wielkiemu koronnemu Stanisławowi Koniecpolskiemu. Dnia 7 maja tego roku Jan Mikołaj i Zofia z Tęczyna Daniłowiczowie wnieśli do grodu chełmskiego akt donacji połowy klucza toporowskiego na rzecz hetmana. Dali mu również

były jedynymi królewszczyznami podskarbiego wielkiego koronnego, na których Zofia z Tęczyńskich uzyskała prawo wspólności. Te dobra domeny Daniłowiczowa zachowała do swojej śmierci. W 1651 r. odnotowano jej posesję w Dryszczowie, Żmudzi oraz w Ratnie. Co jednak ciekawe, w tym samym czasie tenutariuszem w Depułtyczach i Mołodutynie tytułowany był podczaszy chełmski Felicjan Zaklika. W 1653 r. na popisie żołnierza łanowego województwa lubelskiego podskarbina wielka koronna ze swoich dóbr dziedzicznych we wszystkich województwach oraz starostw i dzierżaw królewskich wystawiła 100 porządnej piechoty z rotmistrzem, porucznikiem i muzyką. Por. „Ex parte Zaklika manifestatio”, AP w Lublinie, Chełmskie grodzkie, Inskrypcje (dalej: ChGI), nr 26, s. 527-528 (tu Zaklika jako dzierżawca wspomnianych wsi królewskich); „Nobilis Mierzejowski nomine Magnifica Daniłowiczowa protestatur”, ibidem, s. 676678 (tu Daniłowiczowa jako użytkowniczka starostwa ratneńskiego); „Oblata regestrum de villis regalis Żmudź i Dryszczów", ibidem, s. 691-696 (tu podskarbina wielka koronna jako posesorka tych wsi); „Generosus Lesiecki Vice-Palatinus Chełmensis, Camerarius Granicialis Lublinensis regestrum conscriptorum militum oblatuit”, LGR, nr 81, k. 1116 (popis z 1653 r.).

${ }^{71}$ R. Szczygieł, op. cit., s. 43; „Borzęckiego relatio”, AP w Lublinie, LGR, nr 69, k. 585 (tu Zofia z Tęczyna Daniłowiczowa wspomniana jako dziedziczka i posesorka Końskowoli i Włostowic).

72 A.S. Radziwiłł, op. cit., t. 3: 1640-1647, Wrocław 1972, s. 23; J. Kurtyka, op. cit., s. 213; R. Szczygieł, op. cit., s. 43; S. Grzeszczuk, Opaliński Łukasz, PSB, t. 24, s. 94 (tu jednak błędna informacja o dobrach wniesionych Opalińskiemu przez jego żonę); Jan Mikołaj i Zofia z Tęczyna Daniłowiczowie pozywają Łukasza i Izabelę z Tęczyńskich Opalińskich o Sowoklęski i połowę dóbr Rytwiany, AP w Lublinie, LGR, nr 69, k. 167v.-168v.; Izabela z Tęczyna Opalińska pozywa Jana Mikołaja i Zofię z Tęczyna Daniłowiczów o gwałtowny zjazd dóbr końskowolskich, LGR, nr 70, k. 793v.-794v. 
zgodę na objęcie Toporowa z przyległymi wsiami w realną posesję ${ }^{73}$. Nie wiemy niestety, czy również Izabela Opalińska wyzbyła się na rzecz Koniecpolskiego swojej połowy dóbr toporowskich. Możemy jednak przypuszczać, że tak właśnie się stało, gdyż kasztelan krakowski na pewno władał całością tego klucza, który przeszedł następnie w ręce jego syna, a później wnuka ${ }^{74}$. Na mocy wyroku Trybunału Koronnego podziałowi pomiędzy obie siostry stryjeczne uległy też dobra w województwie sandomierskim. Izabela z Tęczyńskich Opalińska otrzymała na własność klucz z ośrodkiem w Łubnicach (w tym przypadku decydujący okazał się fakt, że jej ojciec wypłacił Katarzynie Leszczyńskiej należne jej sumy zabezpieczone na dobrach kasztelana bełskiego Andrzeja Tęczyńskiego). Przypadła jej również w udziale połowa majętności rytwiańskiej, podczas gdy drugą połowę tej włości objęła Zofia z Tęczyńskich Daniłowiczowa. W związku z tym podziałem Izabela Opalińska została zobowiązana do oczyszczenia z wierzytelności tej części klucza rytwiańskiego, która przypadła Daniłowiczom. W 1647 r. dokonała też aktu przeniesienia sumy 50 tys. florenów z połowy Rytwian na klucz łubnicki. W skład majętności łubnickiej wchodziły wówczas wsie Łubnice, Budziska, Czarna, Czarzyzna, Góra, Grabowa, Łyczba, Orzeł, Otałęska Wola, Otałęż, Przeczów i Stara Wieś w powiecie wiślickim. W kluczu rytwiańskim odnotowano natomiast miasto Staszów oraz wsie Kłoda, Koniemłoty, Niemścice, Oględów, Ruda, Rytwiany, Szydziny (Sydzina), Święcica, Świchów (Sichów Duży), Świchowiec (Sichów Mały) i Tuklęcz w powiecie sandomierskim ${ }^{75}$. Dodajmy także, że w ręce

73 „Illustris et Magnifici Castellani Cracoviensis donatio”, AP w Lublinie, ChGI, nr 25, s. 383-387.

74 „Magnifica Opalińska super Koniecpolski relatio”, AP w Lublinie, LGR, nr 86, k. 307-307v. (w 1660 r. małżonkowie Opalińscy pozwali Stanisława Koniecpolskiego, wnuka i imiennika kasztelana krakowskiego, o kwotę 300 tys. florenów, usiłując zakwestionować ważność transakcji sprzedaży połowy dóbr toporowskich przez Jana Mikołaja i Zofię z Tęczyńskich Daniłowiczów. Na tej podstawie można wnosić, że zmarły niespodziewanie w 1646 r. hetman Stanisław Koniecpolski nie zdążył wywiązać się z wszystkich zobowiązań wobec Łukasza i Izabeli Opalińskich).

75 „M: Opalińska Rytwiany emundando summa in Łubnice transportat et super eandem transportationem Capitulum Chocense consentit", ANK, CCI 265, s. 28-35. Warto jednak zaznaczyć, że przytoczony tu zapis źródła jest niezbyt dokładny, gdyż pominięto w nim przynajmniej kilka wsi, które należały w owym czasie do majętności łubnicko-rytwiańskiej. Dodajmy także, że cała sprawa dotycząca oczyszczenia dóbr rytwiańskich z ciążących na nich zobowiązań wyniknęła z faktu, że w 1629 r. Jan Magnus Tęczyński pożyczył 100 tys. florenów od kapituły w Choczy i obciążył tą sumą dobra rytwiańskie. Izabela Opalińska, przenosząc 50 tys. florenów na Łubnice, pozostawiła drugie 50 tys. florenów na swojej połowie Rytwian. 
Daniłowiczów trafiły też ostatecznie (przed 1642 r.) dobra Sowoklęski w województwie lubelskim ${ }^{76}$.

Z walki o spadek po Janie Magnusie Tęczyńskim zwycięsko wyszła więc jego bratanica, Zofia z Tęczyńskich Daniłowiczowa. W jej posiadaniu znalazły się bowiem dobra międzyrzeckie, klucz końskowolski, Sowoklęski z przyległościami, połowa dóbr rytwiańskich i połowa dóbr toporowskich. Córka wojewody krakowskiego utrzymała się zaś jedynie przy dobrach krakowskich, majętności łubnickiej, połowie Rytwian i połowie Toporowa z przyległościami. Należy jednak podkreślić fakt, że w niektórych przypadkach skłócone ze sobą kuzynki zmuszone były występować wspólnie i solidarnie. Tak było w 1644 r., kiedy obie odziedziczyły spadek po ciotce, wojewodzinie krakowskiej Agnieszce z Tęczyńskich Firlejowej. Wspólną własnością Daniłowiczowej i Opalińskiej stał się wówczas klucz iwanowicki w województwie krakowskim, obejmujący wsie Iwanowice $\mathrm{z}$ folwarkiem, Damice, Krasieniec z folwarkiem, Mikułowice z folwarkiem i Poskitów, które to dobra Firlejowa kupiła w 1635 r. od braci Stanisława i Andrzeja Morskich. Obu potomkiniom Tęczyńskim przypadły również sumy posagowe ciotki zabezpieczone na trzymanej przez nią dożywotnio majętności rogowskiej ${ }^{77}$. Po śmierci drugiej ciotki, Katarzyny z Tęczyńskich Sobieskiej, która zmarła 6 grudnia 1648 r., Zofia Daniłowiczowa i Izabela Opalińska pozwały z kolei Teofilę z Daniłowiczów, wdowę po kasztelanie krakowskim Jakubie Sobieskim, domagając się od niej zwrotu jej posagu i wyprawy ${ }^{78}$.

7 stycznia 1650 r. zmarł mąż Zofii z Tęczyńskich, podskarbi wielki koronny Jan Mikołaj Daniłowicz ${ }^{79}$. Zostawszy wdową, Zofia samodzielnie

${ }^{76}$ Już w 1642 r. Jan Mikołaj Daniłowicz sprzedał na wyderkaf za 30 tys. florenów dobra Sowoklęski (Samoklęski), Ruda i Sery kasztelanowej oświęcimskiej Krystynie z Gajowskich Myszkowskiej. Por. „M. Myszkowskiej admissa intromissio”, AP w Lublinie, LGR, nr 70, k. 1066-1066v.

77 Po śmierci Agnieszki Firlejowej obie siostry stryjeczne przekazały staroście lubelskiemu Zbigniewowi Firlejowi, wnukowi męża ciotki, dobra Rogów w powiecie wiślickim, na których zabezpieczony był jej posag. Każda z nich otrzymała 10 tys. florenów, a więc połowę sumy posagowej wojewodziny krakowskiej. Por. „Morscy Palatinae Cracoviensis Iwanowice donant", ANK, CCI 241, s. 151-160 (akt nabycia Iwanowic przez Agnieszkę Firlejową); M. Thesauraria Regni M. Capitaneo Lublinensi cedit”, CCI 259, s. 720-727 (cesja dóbr rogowskich na Zbigniewa Firleja dokonana przez Zofię Daniłowiczową); „Opalińska Firlejowi cedit”, ibidem, s. 1103-1107 (cesja Rogowa na starostę lubelskiego dokonana przez Izabelę Opalińską).

78 „Illustres et Magnificas Daniłowiczowa ac Opalińska protestantur”, AP w Lublinie, LGR, nr 77, k. 633-633v.; M: Thesauraria Regni ac Succameraria Posnanensis relatio", ibidem, k. 725-725v.; „Daniłowicz consortis tum Opalińska relatio”, LGR, nr 79, k. 9-10.

79 Datę śmierci podskarbiego podaje A.S. Radziwiłl, op. cit., t. 4: 1648-1656, Wrocław 1975, s. 158. Wojciech Hejnosz pisze błędnie, że J.M. Daniłowicz zmarł w 1649 r. Por. 
zarządzała swoim majątkiem. Popadła w dewocję i „fortunę swoję na ubóstwo i cześć Boską wysypała”. Kontynuowała zapoczątkowaną wraz z mężem w połowie lat czterdziestych XVII w. fundację drugiego w Lublinie klasztoru Karmelitanek bosych oraz kościoła pod wezwaniem Niepokalanego Poczęcia Najświętszej Marii Panny w Lublinie. W testamencie spisanym 22 kwietnia 1653 r. zabezpieczyła środki na dokończenie budowy kościoła, klasztoru, domu dla kapelana i służby oraz murów ogrodu klauzurowego. Przeznaczyła też swoje klejnoty, złoto, srebra oraz zapis na 40 tys. złotych na budowę klasztoru Karmelitanek bosych w Poznaniu ${ }^{80}$. Zofia z Tęczyna Daniłowiczowa zmarła bezpotomnie w grudniu (przed 18 tego miesiąca) $1654 \mathrm{r}$. i została pochowana w ufundowanym przez siebie klasztorze Karmelitanek bosych w Lublinie ${ }^{81}$. Wszystkie posiadane przez nią dobra przeszły na Izabelę z Tęczyńskich Opalińską.

idem, op. cit., s. 415. Por. też [A. Kochanowski], Niebieskie planety gornym oddane sphaerom, przy pogrzebie Iaśnie Wielmożnego Iego Mości P. Iana Mikolaia z Zurowa Danilowicza, podskarbiego wielkiego koronnego, przemyskiego, samborskiego, doleńskiego, drohobyckiego, ratyńskiego, etc. etc. starosty. Przez W. O. Alexandra a Jesu Karmelite Bossego w Lublinie w kościele panien karmelitanek bossych, od Iasnie Wielmożney I. M. P. Zophiey chrabianki z Teczyna Daniłowiczowey podkskarbiny wielkiej koronney, wespót z Iaśnie Wielmożnym Małżonkiem, pod tytułem Niepokalanego Poczęcia Panny Przenaświętszey nowo fundowanym, Kraków 1650. Tu na s. 13 stwierdzenie, że Daniłowicz, mając lat 18, ,podczas cecorskiej ekspedycji w wojsku koronnym rotmistrzował". Oznacza to, że urodził się on około $1602 \mathrm{r}$.

${ }^{80} \mathrm{~W}$ uzupełnieniu dodajmy, że decyzję o ufundowaniu klasztoru Karmelitanek bosych w Lublinie podjęli wspólnie Jan Mikołaj i Zofia Daniłowiczowie w latach czterdziestych XVII w. W tym celu zakupili parcele w mieście i rozpoczęli w $1646 \mathrm{r}$. wznoszenie kościoła oraz budynków klasztornych. 31 sierpnia 1649 r. król Jan Kazimierz zatwierdził w całości fundację Daniłowiczów oraz wyjął należące do karmelitanek place i ogród klasztorny spod jurysdykcji świeckiej. Por. B.J. Wanat, Zakon Karmelitów Bosych w Polsce. Klasztory Karmelitów i Karmelitanek Bosych 1605-1975, Kraków 1979, s. 653-654, 663 (tu także o zapisach testamentowych Zofii Daniłowiczowej i środkach przeznaczonych na ufundowanie klasztoru w Poznaniu). W kwestii donacji dla karmelitanek lubelskich obciążających dobra fundatorki por. przyp. 84 w niniejszym tekście.

${ }^{81}$ K. Niesiecki, op. cit., t. 9, s. 66; A. Kłodziński, op. cit., szp. 242, 257; Stanisława Temberskiego roczniki 1647-1656, wyd. W. Czermak, Kraków 1897 (Scriptores Rerum Polonicarum, t. 16), s. 292 (tu stwierdzenie, że Zofia Daniłowiczowa zmarła w końcu grudnia 1654); Liber mortuorum monasterii Strzelnensis ordinis Praemonstratensis, wyd. W. Kętrzyński, Lwów 1888 (MPH, t. 5), s. 766 (tu błędna informacja, że Zofia Daniłowiczowa zmarła 23 grudnia 1655); J. Kurtyka, op. cit., s. 213 (tu również błędna data śmierci Zofii 23 grudnia 1655); R. Szczygieł, op. cit., s. 43 (tu stwierdzenie, że Daniłowiczowa zmarła 16 grudnia 1654). Jak się wydaje, w rzeczywistości Zofia musiała jednak umrzeć w początkach grudnia 1654 r. 18 grudnia tego roku Izabela z Tęczyńskich Opalińska zgłosiła bowiem przed sądem grodzkim lubelskim swoje roszczenie do objęcia dóbr końskowolskich, które przypadły jej w spadku po nieżyjącej już siostrze stryjecznej. Por. „Ex parte Opalińska relatio", AP w Lublinie, LGR, nr 82, k. 1347v.-1348. 
Izabela z Tęczyńskich Opalińska, marszałkowa nadworna koronna

Po śmierci Zofii Daniłowiczowej dziedziczką całej fortuny Tęczyńskich została Izabela. Jedyna córka Jana Magnusa Tęczyńskiego i Doroty z Mińskich z całą pewnością była najmłodsza z rodzeństwa. Mogła się urodzić najwcześniej w 1612 r. Wnioskując jednak na podstawie daty jej zamążpójścia, z pewnością była kilka lat młodsza. 28 listopada 1639 r. poślubiła Łukasza z Bnina Opalińskiego, wówczas starostę pobiedziskiego, następnie podkomorzego poznańskiego (1641-1650) i wreszcie marszałka nadwornego koronnego. Przez wiele lat prowadziła opisane wyżej spory majątkowe ze stryjeczną siostrą. Warto dodać, że mąż Izabeli wyzbył się wszystkich swoich dóbr w Wielkopolsce, zatrzymując w swoim ręku tylko majątki wniesione mu przez żonę. Jedynym nabytkiem małżonków Opalińskich był klucz spytkowicki w województwie krakowskim, powiecie śląskim, który kupili od spadkobierców biskupa warmińskiego Mikołaja Szyszkowskiego. Izabela Opalińska kontynuowała ojcowską fundację klasztoru Kamedułów w Rytwianach. 15 maja 1662 r. straciła męża. Zmarła po 15 maja 1667 r. jako ostatnia z Tęczyńskich. Pozostawiła po sobie dwóch synów - Jana i Stanisława, oraz córkę Zofię, żonę przyszłego marszałka wielkiego koronnego Stanisława Herakliusza Lubomirskiego ${ }^{82}$.

Zachowane w księgach grodzkich krakowskich akty podziału dóbr pomiędzy dzieci Izabeli z Tęczyna Opalińskiej pozwalają na precyzyjne odtworzenie składu latyfundium rodu Tęczyńskich w chwili zejścia ze sceny dziejowej ostatniej ich przedstawicielki. Nie wydaje się, aby trzeba było w tym miejscu ponownie przedstawiać skład poszczególnych kluczy dóbr. Poprzestaniemy zatem na porównaniu stanu posiadania Izabeli Tęczyńskiej z majątkami jej ojca i stryjów. W dobrach międzyrzeckich miała ona, niezmiennie od czasów Gabriela Tęczyńskiego, 1 miasto, 45 wsi

${ }^{82}$ W. Dworzaczek, Genealogia, t. 2, tabl. 94; K. Niesiecki, op. cit., t. 9, s. 67; J. Kurtyka, op. cit., s. 215; S. Grzeszczuk, op. cit., s. 95; BK, TD, Monografie, Opalińscy h. Łodzia (tu jednak błędne informacje o dobrach wniesionych Łukaszowi w posagu przez Izabelę Tęczyńską. Nieprawdziwe jest też stwierdzenie, że przed objęciem podkomorstwa poznańskiego Łukasz Opaliński pełnił urząd podkomorzego kaliskiego); „Oblata executionum bonis oppidi Końska Wola", AP w Lublinie, LGR, nr 93, k. 752v.-754 (tu wzmianka o tym, że Izabela Opalińska żyła jeszcze 15 maja 1667). W uzupełnieniu dodajmy również, że Łukasz Opaliński, sprzedając w październiku 1647 r. dziedziczny klucz sierakowski bratu Krzysztofowi, wojewodzie poznańskiemu, zobowiązał go do spłacenia długu 100 tys. florenów wobec kapituły chockiej i zniesienia tej sumy z dóbr łubnickich i rytwiańskich. Por. A. Sajkowski, Krzysztof Opaliński wojewoda poznański, Poznań 1960, s. 45-46. Por. też A. Biedrzycka, Szyszkowski Mikołaj, PSB, t. 50, Warszawa-Kraków 2014-2015, s. 411-412 (tu informacje o kluczu spytkowickim). 
i 11 folwarków. Po śmierci marszałkowej nadwornej koronnej zaznaczono jedynie, że wieś Szachy pozostaje w zastawie, Rzeczycę dzierżawi Mikołaj Dadźbóg, a Drelów i Ostrówki (z folwarkiem) znajdują się w posesji klasztoru Karmelitanek w Lublinie ${ }^{83}$. Od śmierci Jana Magnusa Tęczyńskiego żadne zmiany nie nastąpiły również w składzie klucza końskowolskiego, w którym odnotowano 1 miasto, 22 wsie i 9 folwarków. Za to ze składu dóbr Sowoklęski ostatecznie ubyła wieś Ruda. W 1668 r. włość tę tworzyły jedynie Sowoklęski i Sery (Wola Serowa). Majętność ta, podobnie jak wsie Osiny (z folwarkiem), Wola Osińska i Wola Profecińska (wraz ze spichlerzem we Włostowicach) pozostawała wówczas w zastawie ${ }^{84}$. Za czasów Izabeli z Tęczyńskich Opalińskiej jej dobra sandomierskie zostały ostatecznie podzielone na klucz rytwiański, w skład którego wchodziły: wieś Rytwiany z zamkiem i folwarkiem, miasto Staszów oraz wsie Kłoda, Koniemłoty z folwarkiem, Niedziałki, Niemścice, Oględów z folwarkiem, Ruda, Sichów Duży z folwarkiem, Sichów Mały, Sichówek z folwarkiem, Szczeka z folwarkiem, Szydziny (Sydzina), Święcica i Tuklęcz; oraz majętność łubnicką, czyli wieś Łubnice z dworem i folwarkiem, Borki, Budziska z folwarkiem, Czarne, Czarzyzna, Czołno, Folwark, Góra, Grabowa, Łyczba, Orzelec Mały, Orzelec Wielki, Orzeł z folwarkiem, Otałęska Wola, Otałęż, Przeczów i Stara Wieś. W sumie było to 1 miasto, 31 wsi i 9 folwarków ${ }^{85}$.

83 „M.M. Opalińskich divisio”, ANK, CCI 292, s. 2423-2424; „Eorundem M.M. Opalińskich divisio", CCI 295, s. 196, 200-201.

84 „Opalińscy Lubomirskiej donant”, ANK, CCI 292, s. 2337; „MM. Opalińskich divisio”, ibidem, s. 2422, 2424; „Eorundem M.M. Opalińskich divisio”, CCI 295, s. 194-195. Warto tu dodać, że fundując klasztor Karmelitanek w Lublinie, Zofia z Tęczyńskich Daniłowiczowa w 1648 r. obciążyła Sowoklęski zapisem 135 tys. florenów na rzecz tego zgromadzenia. Zapisała też karmelitankom czynsz wyderkafowy w wysokości 7 tys. florenów rocznie z dóbr łubnicko-rytwiańskich, na których ulokowała kolejnych 100 tys. florenów donacji na rzecz klasztoru. Por. „Ex parte Illustris Opaliński posita citationis relatio”, AP w Lublinie, LGR, nr 85, k. 61v.-62v.; „Ex parte Generosa Opalińska posita citationis relatio”, ibidem, k. 375v.-379v.; „Illustris et Magnifica Opalińska contra officiales Leopoliensis nec non Niezabytowski relatio", ibidem, k. 881-882v. Jak można przypuszczać, w 1667 r. Sowoklęski pozostawały w zastawie lubelskich karmelitanek. Jeśli chodzi natomiast o Osiny z przyległościami, to w 1661 r. Łukasz i Izabela Opalińscy zastawili ten klucz za 36550 florenów wojewodzie wołyńskiemu Michałowi Jerzemu ks. Czartoryskiemu i jego żonie, Eufrozynie ze Stanisławskich. W 1667 r. Czartoryscy przyjęli sumę 32 tys. florenów od kasztelana kruszwickiego Samuela Konstantego Szczawińskiego i dali mu intromisję w te dobra. Por. „Ducis Czartoriensis et consorti eius intromissio”, AP w Lublinie, LGR, nr 87, k. 563v.-564; „Magnificus Szczawiński intromissus", LGR, nr 93, k. 554v.-555.

85 „M.M. Opalińskich divisio”, ANK, CCI 292, s. 2425-2426; „Eorundem M.M. Opalińskich divisio”, CCI 295, s. 195-197. W porównaniu do czasów Andrzeja Tęczyńskiego, 
Niewielkie zmiany zaszły również po 1637 r. w dobrach krakowskich. W kluczu tęczyńskim pojawiły się nieznane wcześniej wsie Morawiczka z folwarkiem, Tęczyn $\mathrm{z}$ folwarkiem oraz Wola. W sumie zatem w 1667 r. włość ta składała się z 1 miasta, 22 wsi całych, 5 części wsi i 10 folwarków. Z majątków wchodzących w skład dawnego latyfundium Jana Magnusa Tęczyńskiego jego córka utrzymała w swoich rękach wsie Bachowice z folwarkiem i Grodzisko z folwarkiem. Wyzbyła się natomiast ostatecznie, nie wykupując tych wiosek od spadkobierców Mikołaja Wizemberga, części Jankowic i całej wsi Obrazowice (Obrażejowice). Łukasz i Izabela z Tęczyńskich Opalińscy mieli także w województwie krakowskim odziedziczoną po Agnieszce Firlejowej majętność iwanowicką (dwór, 5 wsi, 3 folwarki) oraz kupione przez nich samych dobra spytkowickie - wsie Spytkowice z zamkiem i folwarkiem, Brodła z folwarkiem, Mirów z folwarkiem, Okleśna z folwarkiem i Rusocice $\mathrm{z}$ folwarkiem. Ogółem, w województwie krakowskim latyfundium ostatniej z Tęczyńskich obejmowało 1 miasto, 34 wsie całe, 5 części wsi i 20 folwarków. W Krakowie dysponowała ona pozyskaną przez męża kamienicą Firlejowską (dawniej Bonerowską) w rynku oraz odziedziczonym po ojcu dworem Tęczyńskim ${ }^{86}$.

W chwili śmierci Izabeli z Tęczyńskich Opalińskiej jej dobra składały się z 4 miast, 134 wsi całych, 5 części wsi i 49 folwarków. W ogromnej większości były to majątki, którymi władał już jej ojciec. Jedynym ubytkiem z dawnego latyfundium wojewody krakowskiego okazał się klucz toporowski. Jego sprzedaż została jednak zrekompensowana poprzez pozyskanie przez Łukasza i Izabelę Opalińskich Iwanowic i Spytkowic z przyległościami. Warto też zauważyć, że dobra posiadane przez ostatnich Tęczyńskich zapewniały każdemu z nich status magnacki. Wszyscy synowie wojewody krakowskiego Andrzeja osiągnęli urzędy wielkosenatorskie - Gabriel województwo lubelskie, Andrzej kasztelanię bełską, a Jan Magnus, podobnie jak ojciec, województwo krakowskie. Każdy z nich uczestniczył też w eksploatacji dóbr domeny królewskiej. W kręgu

ze składu dóbr sandomierskich ubyły: pusta wieś Gorzechów oraz wsie Stary Staszów, Tatary i Zaraz. Dzięki donacji Jana Magnusa Tęczyńskiego na własność eremu Kamedułów w Rytwianach przeszły zaś Sieragi, Wolica i Zrębin. Na ich miejsce przybyły natomiast osady nowe - Czarne, Czołno, Folwark, Łyczba i Sichówek. Warto odnotować, że spośród tych ostatnich tylko wieś Łyczba została zaznaczona na mapie województwa sandomierskiego z końca XVI w. Por. Województwo sandomierskie, mapa 1.

86 „M.M. Opalińskich divisio”, ANK, CCI 292, s. 2425-2426; „Eorundem M.M. Opalińskich divisio", CCI 295, s. 198-200. Por. też Rejestr poborowy województwa krakowskiego $z$ roku 1680 wraz z aneksem miast według rejestru z roku 1655, oprac. E. Trzyna, S. Żyga, red. S. Inglot, Wrocław 1959, s. 15, 29-33, 36-40, 55, 119-120. 
przedstawicieli rodzin wielkosenatorskich zawarły małżeństwa ich siostry. Agnieszka poślubiła wojewodę krakowskiego, Katarzyna wojewodę lubelskiego, a Zofia przyszłego wojewodę kaliskiego. Dwie ostatnie przedstawicielki tego rodu wyszły natomiast za ministrów stanu senatorskiego. Zofia została żoną podskarbiego wielkiego koronnego, a Izabela marszałka nadwornego koronnego. Do tradycji znakomitego rodu Tęczyńskich starali się też nawiązać ich bezpośredni spadkobiercy. Synowie Łukasza i Izabeli Opalińskich konsekwentnie pisali się bowiem z Tęczyna Opalińskimi. Dodajmy wreszcie na koniec, że dobra wchodzące w skład latyfundium rodu Tęczyńskich w XVIII stuleciu przeszły w ręce dalszych potomków po kądzieli wojewody krakowskiego Jana Magnusa. Po bezpotomnej śmierci synów Izabeli Opalińskiej odziedziczyła je bowiem ich siostrzenica, Elżbieta Helena Lubomirska $(* 1669 † 1729)$, żona kasztelana krakowskiego i hetmana wielkiego koronnego Adama Mikołaja Sieniawskiego (*1666 † 1726). Następnie wszystkie dobra Sieniawskich przejęła ich jedyna córka Zofia Maria $(* 1699$ † 1771) oraz jej drugi mąż, wojewoda ruski August ks. Czartoryski $\left({ }^{*} 1697\right.$ † 1782). Kiedy zaś dobra Augusta i Zofii Czartoryskich podzielono pomiędzy ich dzieci - Adama Kazimierza $(* 1734$ † 1823) i Izabelę (Elżbietę) $(* 1736$ † 1816), podziałowi uległo również, pozostające do tej pory w niezmienionym kształcie w rękach kolejnych właścicieli, dawne latyfundium rodu Tęczyńskich. Końskowola, Sowoklęski (zwane teraz Samoklęskami) i Międzyrzec przypadły bowiem generałowi ziem podolskich Adamowi Kazimierzowi ks. Czartoryskiemu, a Rytwiany, Łubnice, Tęczyn, Iwanowice i Spytkowice otrzymała Elżbieta (Izabela) z ks. Czartoryskich ks. Lubomirska, żona marszałka wielkiego koronnego Stanisława. Do końca istnienia państwa polsko-litewskiego, a także długo potem, dobra należące do wygasłego w XVII w. rodu Tęczyńskich stanowiły więc istotną część składową potężnych latyfundiów generała ziem podolskich oraz jego siostry, zwanej przez współczesnych księżną marszałkową.

\section{Streszczenie}

Przedmiotem badań podjętych przez autora niniejszego artykułu są dzieje latyfundium możnego rodu Tęczyńskich herbu Topór w XVII w. Od chwili jego podziału w 1601 r. pomiędzy synów wojewody krakowskiego Andrzeja Tęczyńskiego, dobra te znajdowały się w rękach pięciorga posiadaczy - wojewody lubelskiego Gabriela, kasztelana bełskiego Andrzeja, wojewody krakowskiego Jana Magnusa oraz Zofii, córki Gabriela, i Izabeli, córki Jana Magnusa. Wszyscy oni dysponowali majątkami, które zapewniały im przynależność do warstwy magnackiej. W przypadku każdej 
z tych postaci autor przedstawia istotne uzupełnienia do ich biografii. Najważniejsze wydaje się ustalenie, że wojewoda lubelski Gabriel pozostawił po sobie nie dwie, a tylko jedną córkę. Jej matką była zaś nie pierwsza, a druga żona Tęczyńskiego, Elżbieta z ks. Radziwiłłów. Pierwsza małżonka Gabriela - Barbara ks. Zbaraska zmarła bowiem bezpotomnie kilka miesięcy po ślubie. Z jej ogromnych dóbr wojewoda lubelski zdołał przejąć tylko Międzyrzec z przyległościami, który na stałe wszedł w skład latyfundium Tęczyńskich. Po śmierci obu starszych braci wszystkie dobra rodowe skupił w swoim ręku wojewoda krakowski Jan Magnus Tęczyński. Władał on latyfundium obejmującym 5 miast, 137 wsi i części wsi oraz 43 folwarki. Po śmierci wojewody zaciętą walkę o pozostawiony przez niego majątek stoczyły jego bratanica Zofia, która poślubiła Jana Mikołaja Daniłowicza, oraz córka Izabela, żona Łukasza Opalińskiego. Dopiero po bezpotomnej śmierci Zofii Daniłowiczowej w 1654 r. wszystkie dobra Tęczyńskich znalazły się w rękach Izabeli i jej małżonka. W chwili śmierci Izabeli, która zmarła w 1667 r. jako ostatnia przedstawicielka rodu Tęczyńskich, jej latyfundium składało się z 4 miast, 134 wsi całych, 5 części wsi i 49 folwarków. Był to jeden z największych kompleksów majątkowych na etnicznych ziemiach polskich wchodzących w skład Korony.

\section{The Tęczyńskis' Latifundium in the Seventeenth Century. Estates and Owners}

This article investigates the history of the latifundium of the mighty Tęczyński family of the Topór coat of arms in the seventeenth century. After it was divided in 1601 between the sons of Andrzej Tęczyński, palatine (wojewoda) of Cracow, the estate was in the hands of five owners: Gabriel, palatine of Lublin Andrzej, castellan of Bełz Jan Magnus, palatine of Cracow and two women: Zofia, Gabriel's daughter, and Izabela, Jan Magnus's daughter. All of them had a share sufficient to categorise them among the magnate class. In the case of each of them, the author provides important additions to their biographies. The most important is his demonstration that Gabriel had only one daughter, not two as was previously thought. Her mother was not Gabriel's first, but his second wife, Elżbieta, née Radziwiłł. His first wife, Barbara, duchess of Zbarazh, died childless several months after the wedding. From the vast estates Barbara had brought into the marriage, Gabriel managed to keep only Międzyrzec with its adjacent areas, which were permanently added to the Tęczyńskis' latifundium. After the death of both his older brothers, all the family lands were gathered by Jan Magnus Tęczyński. His latifundium included five towns, 137 villages and parts of villages, and 43 manors. After his death, a fierce battle for the property left by him was fought by his niece Zofia, married to Jan Mikołaj Daniłowicz, and his daughter Izabela, the wife of Łukasz Opaliński. It was not until the death of Zofia Daniłowicz without an heir in 1654 that all the Tęczyńskis' estates returned to Izabela and her husband. Upon the death of Izabela in 1667 as the last member of the Tęczyński family, her estate included four towns, 134 whole villages, five parts of villages, and 49 manors. It was one of the largest landed estates in the in the heartlands of the Kingdom of Poland. 


\section{Bibliografia}

\section{Edycje źródłowe}

Cynerski Rachtamowicz Jan, Thesaurus meritorum. Ad festum Nuptiale Illustrissimi ac Magnifici Dni, D. Ioannis Nicolai a Zurow Daniłowicz, Supremi Thesaurarij Regni, Praemislien. Samborien. Drohobycen. Colsen. Korsunen. Ratinen. etc. etc. etc. Capitanei. Et Lectissimae Virginis Sophiae Comitissae a Tęczyn, Illustriss: olim et Mag. Dni, Stanislai Comitis a Tęczyn, Palatini Lublinensis unicae Filiae, Cracoviae 1638.

Fontes Lublinenses, t. 9: Miscellanea Lublinensia. Raptularz Zbigniewa Borowskiego z lat 1604-1644. Taksa cen towarów sporządzona przez komisję sejmowa w Lublinie w 1628 r., oprac. Henryk Gmiterek, Archiwum Państwowe w Lublinie, Lublin 2017.

Hińcza Marcin, Plessy anyołow Jezusowi narodzonemu, najswiętszego Krzyża tance, Kraków 1636 [właściwie 1638].

[Kochanowski Andrzej], Niebieskie planety gornym oddane sphaerom, przy pogrzebie Iaśnie Wielmożnego Iego Mości P. Iana Mikolaia z Zurowa Danilowicza, podskarbiego wielkiego koronnego, przemyskiego, samborskiego, doleńskiego, drohobyckiego, ratyńskiego, etc. etc. starosty. Przez W. O. Alexandra a Jesu Karmelite Bossego w Lublinie $w$ kościele panien karmelitanek bossych, od Iasnie Wielmożney I. M. P. Zophiey chrabianki z Teczyna Daniłowiczowey podkskarbiny wielkiej koronney, wespół z Iaśnie Wielmożnym Małżonkiem, pod tytułem Niepokalanego Poczęcia Panny Przenaświętszey nowo fundowanym, Kraków 1650.

Księga wpisów kancelarii koronnej podkanclerzego Tomasza Zamoyskiego z lat 1628-1635 ze zbiorów sztokholmskiego Riksarkivet sygnatura Skokloster E[nskilda] 8636, oprac. Wojciech Krawczuk, Historia Iagellonica, Kraków 1999 (Sumariusz Metryki Koronnej, t. 1).

Liber mortuorum monasterii Strzelnensis ordinis Praemonstratensis, wyd. Wojciech Kętrzyński, Gubrynowicz \& Schmidt, Lwów 1888 (MPH, t. 5), s. 719-767.

Ossoliński Jerzy, Pamiętnik, oprac. Władysław Czapliński, PIW, Warszawa 1976.

Ossoliński Zbigniew, Pamiętnik, oprac. Józef Długosz, PIW, Warszawa 1983.

Pierzakowicz Modest, Gorskość śmierci na pogrzebie Theophili z Tęczyna Kopciowey woiewodzanki lubelskiey $w$ kościele opolskim wspomniona, Lublin [1635].

Radziwiłł Albrycht Stanisław, Memoriale rerum gestarum in Polonia 1632-1656, oprac. Adam Przyboś, Roman Żelewski, Ossolineum, t. 2: 1634-1639, Wrocław 1970; t. 3: 1640-1647, Wrocław 1972; t. 4: 1648-1656, Wrocław 1975.

Rejestr poborowy województwa krakowskiego z roku 1629, oprac. Wanda Domin [et al.], red. Stefan Inglot, Ossolineum, Wrocław 1956.

Rejestr poborowy województwa krakowskiego z roku 1680 wraz z aneksem miast wedtug rejestru z roku 1655, oprac. Edward Trzyna, Stanisław Żyga, red. Stefan Inglot, Ossolineum, Wrocław 1959.

Rejestr poborowy województwa lubelskiego (powiat lubelski i urzędowski z r. 1626, ziemia łukowska z r. 1620), oprac. Jan Kolasa, Kamila Schuster, red. Stefan Inglot, PWN, Wrocław 1957.

Sobieski Jakub, Mowy pogrzebowe, wyd. Maria Barłowska, Małgorzata Ciszewska, Instytut Badań Literackich PAN Wydawnictwo, Warszawa 2019. 
Stanisława Temberskiego roczniki 1647-1656, wyd. Wiktor Czermak, nakł. Akademii Umiejętności, Kraków 1897 (Scriptores Rerum Polonicarum, t. 16).

Trepka Walerian Nekanda, Liber generationis plebeanorum (,Liber chamorum”), cz. 1: Wstẹpy wydawców i tekst, wyd. Włodzimierz Dworzaczek, Julian Bartyś, Zbigniew Kuchowicz, red. Włodzimierz Dworzaczek, Ossolineum, Wrocław-WarszawaKraków 1963.

Ziemie Ruskie, Ukraina (Kijów-Bracław), dział 2, wyd. Aleksander Jabłonowski, Gebethner \& Wolf, Warszawa 1893 (Źródła dziejowe, t. 21, Polska XVI wieku pod względem geograficzno-statystycznym, t. 10).

\section{Opracowania}

Anusik Zbigniew, Dobra ziemskie książą Zbaraskich w XVI i XVII wieku, w: idem, Studia i szkice staropolskie, Wydawnictwo Uniwersytetu Łódzkiego, Łódź 2011, s. 495-552.

Anusik Zbigniew, Dobra ziemskie Tęczyńskich w XIV-XVII wieku, w: idem, Studia i szkice staropolskie, Wydawnictwo Uniwersytetu Łódzkiego, Łódź 2011, s. 175-217.

Anusik Zbigniew, Dwa ostatnie pokolenia Tęczyńskich herbu Topór. Kilka korekt i uzupetnień dotyczacych genealogii rodu, "Przegląd Historyczny” 111, 2020, 4, s. 725-743.

Anusik Zbigniew, Latyfundia książąt Zbaraskich w XVI i XVII wieku, „Przegląd Nauk Historycznych" 8, 2009, 1, s. 17-77.

Anusik Zbigniew, Latyfundia panów na Tęczynie. Kilka refleksji w związku z książka Janusza Kurtyki, „Przegląd Nauk Historycznych” 2, 2003, 2 (4), s. 217-256.

Atlas historyczny Rzeczypospolitej Polskiej, Epoka przełomu z wieku XVI-go na XVII-ty, Dział II-gi, „Ziemie ruskie” Rzeczypospolitej, oprac. Aleksander Jabłonowski, Akademia Umiejętności w Krakowie, Warszawa-Wiedeń 1899-1904.

Barłowska Maria, „Bo przystoi by mężne tak wieziono ciała”. Mowy przy wyprowadzaniu ciała rycerza z obozu, „Wschodni Rocznik Humanistyczny” 7, 2010, s. 57-69.

Biedrzycka Agnieszka, Szyszkowski Mikołaj, PSB, t. 50, Warszawa-Kraków 2014-2015, s. 406-413.

Bondyra Wiesław, Własność ziemska w województwie bełskim w czasach saskich, Wydawnictwo UMCS, Lublin 2015.

Boniecki Adam, Herbarz polski, t. 6, 11, Gebethner \& Wolf, Warszawa 1903, 1907.

Borkowska Małgorzata, Zakonnice pominięte w tablicach Dworzaczka, „Nasza Przeszłość" 97, 2002, s. 259-302.

Byliński Janusz, Sejm z 1611 roku. W nowym opracowaniu, E-Wydawnictwo. Prawnicza i Ekonomiczna Biblioteka Cyfrowa. Wydział Prawa, Administracji i Ekonomii Uniwersytetu Wrocławskiego, Wrocław 2016.

Chłapowski Krzysztof, Realizacja reform egzekucji dóbr 1563-1665. Sprawa zastawów królewszczyzn małopolskich, PWN, Warszawa 1984.

Chłapowski Krzysztof, Starostowie w Małopolsce 1565-1668, w: Społeczeństwo staropolskie. Studia i szkice, t. 4, red. Anna Izydorczyk, Andrzej Wyczański, PWN, Warszawa 1986, s. 105-178. 
Chynczewska-Hennel Teresa, Ostrogski Janusz, PSB, t. 24, Wrocław 1979, s. 481-486. Dworzaczek Włodzimierz, Genealogia, t. 2 (Tablice), PWN, Warszawa 1959.

Dworzaczek Włodzimierz, Gostomski Jan, PSB, t. 8, Wrocław-Warszawa-Kraków 1959-1960, s. 366-367.

Filipczak-Kocur Anna, Proces o spadek po księżniczce Barbarze Zbaraskiej-Tęczyńskiej, w: Vetera novis augere. Studia i prace dedykowane profesorowi Wacławowi Uruszczakowi, t. 1, red. Stanisław Grodziski [et.al.], Wydawnictwo Uniwersytetu Jagiellońskiego, Kraków 2010, s. 221-230.

Gil Czesław, Karmelici bosi w Polsce 1605-1655, „Nasza Przeszłość” 18, 1977, s. 114-125. Gmiterek Henryk, Sobieski Marek, PSB, t. 39, Warszawa-Kraków 1999-2000, s. 502-504. Gruszecki Stefan, Miński Stanisław, PSB, t. 21, Wrocław 1976, s. 320-322.

Grzeszczuk Stanisław, Opaliński Łukasz, PSB, t. 24, Wrocław 1979, s. 93-96.

Hejnosz Wojciech, Daniłowicz Jan Mikołaj, PSB, t. 4, Kraków 1938, s. 415-416.

Kłodziński Abdon, Tęczyńscy. Pogląd na rozwój, zamożność i znaczenie rodu, „Sprawozdania Komisyi do badania Historyi Sztuki" 9, 1913, szp. 243-260.

Kempa Tomasz, Mikołaj Krzysztof Radziwiłł Sierotka (1549-1616) wojewoda wileński, Semper, Warszawa 2000.

Kotowa Ida, Barzina z Ojrzanowa Dorota, PSB, t. 1, Kraków 1935, s. 346.

Kurtyka Janusz, Latyfundium tęczyńskie. Dobra i właściciele (XIV-XVII wiek), Księgarnia Akademicka, Kraków 1999.

Lepszy Kazimierz, Firlejowa Agnieszka, PSB, t. 7, Kraków 1948-1958, s. 17-18.

Lubczyński Mariusz, Tarło Piotr Aleksander (Aleksander Piotr), PSB, t. 52, WarszawaKraków 2018-2019, s. 311-314.

Lulewicz Henryk, Radziwiłł Mikołaj Krzysztof zwany Sierotka, PSB, t. 30, Wrocław 1987, s. $349-361$.

Łoziński Władysław, Prawem i lewem. Obyczaje na Czerwonej Rusi w pierwszej połowie XVII wieku, t. 1-2, Wydawnictwo Literackie, Kraków 1957 (wyd. 5).

Niesiecki Kasper, Herbarz polski, t. 9, wyd. Jan N. Boborowicz, Breitkopft \& Haertel, Lipsk 1842.

Opaliński Edward, Rodziny wielkosenatorskie w Wielkopolsce, na Kujawach i na Mazowszu za Zygmunta III. Podstawy karier, DiG, Warszawa 2007.

Rachuba Andrzej, Sapieha Kazimierz Leon, PSB, t. 35, Warszawa-Kraków 1994, s. 31-37.

Sajkowski Alojzy, Krzysztof Opaliński wojewoda poznański, Wydawnictwo Poznańskie, Poznań 1960.

Sajkowski Alojzy, Staropolska miłość. Z dawnych listów i pamiętników, Wydawnictwo Poznańskie, Poznań 1981.

Sajkowski Alojzy, Włoskie przygody Polaków. Wiek XVI-XVIII, PIW, Warszawa 1973.

Słownik geograficzny Królestwa Polskiego i innych krajów słowiańskich, t. 9, 10, 12, red. Bronisław Chlebowski, Filip Sulimierski, Władysław Walewski, nakład Władysława Walewskiego, Warszawa 1888, 1889, 1892.

Sokołowski Wojciech, Politycy schyłku złotego wieku. Małopolscy przywódcy szlachty i parlamentarzyści w latach 1574-1605, Wydawnictwo Sejmowe, Warszawa 1997.

Szczygieł Ryszard, od lokacji do upadku szlacheckiej Rzeczypospolitej, w: Dzieje Końskowoli, red. Ryszard Szczygieł, Końskowolskie Towarzystwo Regionalne, Lublin 1988, s. 35-60. 
Urban Wacław, Daty życia niektórych osób z XVI w. związanych z Krakowem. Przyczynki źródłowo-biograficzne, „Biuletyn Biblioteki Jagiellońskiej” 41, 1991, s. 81-100.

Urzędnicy

t. 3, z. 2 - Urzędnicy województwa betskiego i ziemi chełmskiej XIV-XVIII wieku. Spisy, oprac. Henryk Gmiterek, Ryszard Szczygieł, Biblioteka Kórnicka, Kórnik 1992.

t. 4, z. 2 - Urzędnicy województwa krakowskiego XVI-XVIII wieku. Spisy, oprac. Stanisław Cynarski, Alicja Falniowska-Gradowska, Biblioteka Kórnicka, Kórnik 1990.

t. 4, z. 3 - Urzędnicy województwa sandomierskiego XVI-XVIII wieku. Spisy, oprac. Krzysztof Chłapowski, Alicja Falniowska-Grabowska, Biblioteka Kórnicka, Kórnik 1993.

t. 4, z. 4 - Urzędnicy województwa lubelskiego XVI-XVIII wieku. Spisy, oprac. Witold Kłaczewski, Wacław Urban, Biblioteka Kórnicka, Kórnik 1991.

Wanat Benignus Józef, Zakon Karmelitów Bosych w Polsce. Klasztory Karmelitów i Karmelitanek Bosych 1605-1975, Wydawnictwo OO Karmelitów Bosych, Kraków 1979. Wasilewski Tadeusz, Kiszka Krzysztof, PSB, t. 12, Wrocław-Warszawa-Kraków 1966 1967, s. 510-511.

Województwo krakowskie w drugiej połowie XVI wieku, cz. 2: Komentarz, indeksy, red. Henryk Rutkowski, oprac. Krzysztof Chłapowski [et al.], Neriton, Warszawa 2008 (Atlas historyczny Polski. Mapy szczegółowe XVI wieku, 1).

Województwo sandomierskie $w$ drugiej połowie XVI wieku, red. Władysław Pałucki, cz. 1: Mapy, plany, PWN, Warszawa 1993 (Atlas historyczny Polski. Mapy szczegółowe XVI wieku, 2).

Biogram: Zbigniew Anusik, prof. dr hab., kierownik Katedry Historii Nowożytnej w Instytucie Historii Uniwersytetu Łódzkiego. Zainteresowania badawcze: historia Polski i powszechna XVII i XVIII w.; historia Szwecji XVI-XVIII w.; stosunki polsko-szwedzkie w XVII i XVIII w.; historia dyplomacji polskiej i powszechnej XVIII w.; dzieje Wielkiej Rewolucji Francuskiej 1789-1799; elity dawnej Rzeczypospolitej; struktura własności ziemskiej w Rzeczypospolitej w pierwszej połowie XVII w.; kontakt: zbigniew.anusik@uni.lodz.pl.

Author: Zbigniew Anusik, professor, head of the Department of Modern History in the Institute of History, University of Łódź. His research interests: Polish and general history of the seventeenth and eighteenth centuries, history of Sweden in the sixteenth to eighteenth centuries, Polish-Swedish relations in the seventeenth and eighteenth centuries, the history of Polish and general diplomacy of the eighteenth century, the history of the French Revolution 1789-99, the elites of the Polish-Lithuanian Commonwealth, the structure of landed property in the Polish-Lithuanian Commonwealth in the first half of the seventeenth century; contact: zbigniew.anusik@uni.lodz.pl. 